\title{
Electrical Properties of Frog Saccular Hair Cells: Distortion by Enzymatic Dissociation
}

\author{
Cecilia E. Armstrong and William M. Roberts \\ Institute of Neuroscience, University of Oregon, Eugene, Oregon 97403-1254
}

\begin{abstract}
Although it is widely accepted that the electrical resonance seen in many types of auditory and vestibular hair cells contributes to frequency selectivity in these sensory systems, unexplained discrepancies in the frequency $(f)$ and sharpness (Q) of tuning have raised serious questions. For example, enzymatically dissociated hair cells from bullfrog (Rana catesbeiana) sacculus resonate at frequencies well above the range of auditory and seismic stimuli to which the sacculus is most responsive. Such disparities, in addition to others, have led to the proposal that electrical resonance alone cannot account for frequency tuning. Using grassfrog (Rana pipiens) saccular hair cells, we show that the reported discrepancies in $f$ and $Q$ in this organ can be explained by the deleterious effects of enzyme (papain) exposure during cell dissociation. In patch-clamp studies of hair cells in a semi-intact epithelial preparation, we observed a variety of voltage behaviors with frequencies of
\end{abstract}

Auditory and vestibular processing involves the decomposition of complex stimuli, such as sound waves and substrate vibrations, into their constituent frequency components. A remarkable variety of sophisticated mechanisms, often used in concert, have evolved for this purpose. In all vertebrates, the physical properties of structures in the inner ear surrounding the mechanosensory hair cells serve as initial filters. In mammals, there is good evidence that the exquisite sensitivity and sharp frequency discrimination of the cochlea are achieved through active mechanical feedback provided by the outer hair cells (for review, see Ashmore and Kolston, 1994). Such a feedback mechanism has not been demonstrated in nonmammalian vertebrates, although there is ample evidence that hair cells from these species can exert forces when stimulated (for review, see Hudspeth, 1997). Many researchers hold that frequency discrimination in nonmammalian vertebrates is attributable to the electrical properties of the hair cells. Evidence of electrical tuning is widespread and has been studied extensively in frog, turtle, chick, and fish. Our work focuses on electrical tuning in the frog sacculus, a vestibular organ predominantly responsive to seismic stimuli (Moffat and $\mathrm{Ca}$ pranica, 1976).

In an electrically tuned hair cell, the membrane potential typically undergoes damped sinusoidal oscillations in response to

\footnotetext{
Received Jan. 20, 1998; accepted Feb. 9, 1998.

This work was supported by National Institutes of Health Grant NS27142, predoctoral fellowship Training Grant GM07257, and a Grant from the Medical Research Foundation of Oregon. We thank Drs. B. D. Anson, B. Edmonds, D. Lenzi, and P. M. O'Day for careful dissection of this manuscript, J. W. Runyeon for scanning electron microscopy, and M. W. Armstrong for Canis familiaris hair.

Correspondence should be addressed to Dr. William M. Roberts, Institute of Neuroscience, 1254, University of Oregon, Eugene, OR 97403-1254.

Copyright (C) 1998 Society for Neuroscience $0270-6474 / 98 / 182962-12 \$ 05.00 / 0$
}

35-75 Hz. This range is well below the range of resonant frequencies observed in enzymatically dissociated hair cells and more in tune with the frequency range of natural stimuli to which the sacculus is maximally responsive. The sharpness of tuning also agreed with previous studies using natural stimuli. In contrast to results from enzymatically dissociated hair cells, both a calcium-activated $\mathrm{K}^{+}\left(\mathrm{K}_{\mathrm{Ca}}\right)$ current and a voltagedependent $\mathrm{K}^{+}\left(\mathrm{K}_{\mathrm{V}}\right)$ current contributed to the oscillatory responses of hair cells in the semi-intact preparation. The properties of the $\mathrm{K}_{\mathrm{Ca}}$ and the $\mathrm{Ca}^{2+}$ current were altered by enzymatic dissociation. $\mathrm{K}_{\mathrm{V}}$ and a small-conductance calciumactivated $\mathrm{K}^{+}$current were apparently eliminated.

Key words: frog saccular hair cells; semi-intact epithelial preparation; enzymatically dissociated; electrical resonance; voltage oscillations; $\mathrm{K}^{+}$currents; $\mathrm{Ca}^{2+}$ current; papain

injected current steps (Crawford and Fettiplace, 1981; Lewis and Hudspeth, 1983; Fuchs et al., 1988; Sugihara and Furukawa, 1989; Steinacker and Romero, 1992). In the turtle cochlea, the frequency of this "electrical resonance" is thought to determine the characteristic auditory frequency of the hair cell, the frequency of sound that produces the maximal voltage response (Crawford and Fettiplace, 1981). According to this view, a hair cell's characteristic auditory frequency is governed by the kinetics of the ionic conductances that generate its resonance (for review, see Fettiplace, 1987).

Measurements of electrical resonance in enzymatically dissociated bullfrog saccular hair cells suggest that these hair cells are most sensitive to stimuli of $120 \pm 24 \mathrm{~Hz}$ (mean \pm SD) (Hudspeth and Lewis, 1988b). In contrast, experiments using more intact preparations suggest that this organ is maximally sensitive to a lower range of frequencies, generally between 20 and $100 \mathrm{~Hz}$ (Koyama et al., 1982; Ashmore, 1983; Lewis, 1988; Yu et al., 1991). Such differences in frequency, in addition to disparities in the sharpness of tuning, have led a number of researchers to conclude that the electrical properties of hair cells are not the major determinants of frequency discrimination (Lewis, 1988; Eatock et al., 1993). We now show that much of the discrepancy in frog sacculus is an artifact of enzyme exposure, and that the electrical tuning of these cells may, in fact, account for the frequency selectivity of this organ.

Using whole-cell and perforated patch recording methods in conjunction with standard pharmacological agents, we compared the membrane properties of enzymatically dissociated grassfrog saccular hair cells and hair cells in a semi-intact epithelial preparation. Our results from enzymatically dissociated hair cells were identical to previous reports from bullfrog (Lewis and 

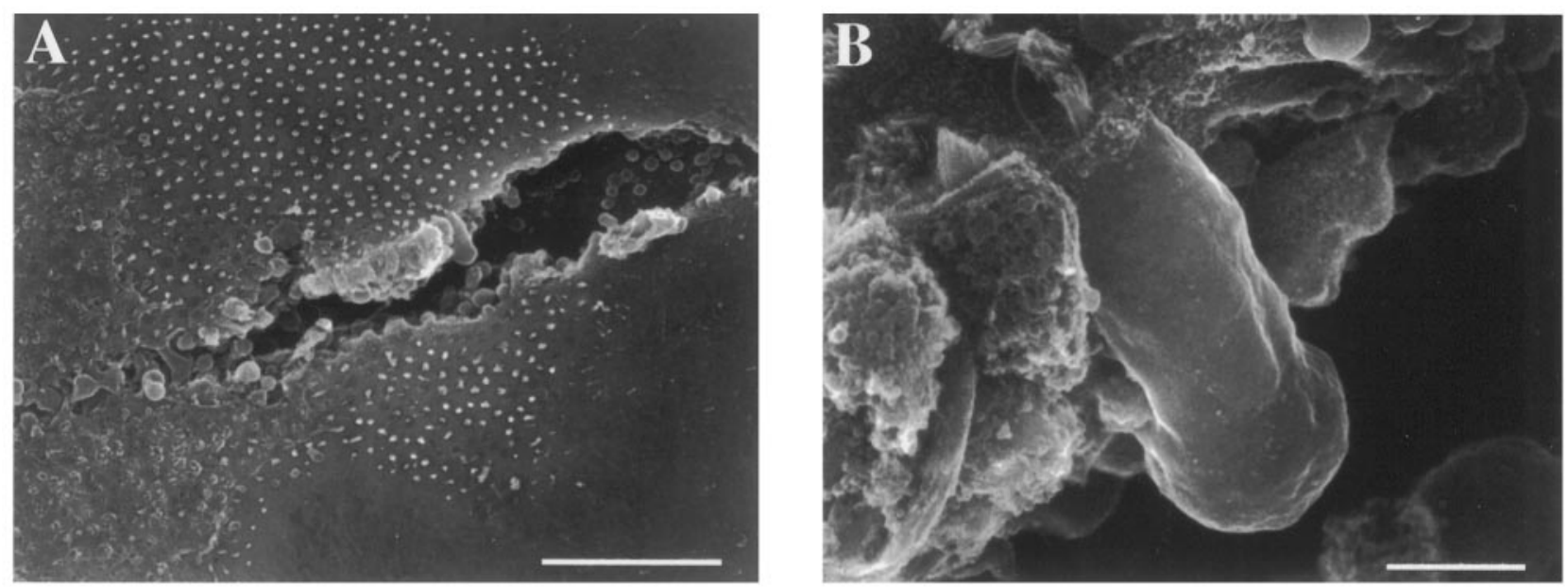

Figure 1. Scanning electron micrograph illustrating the semi-intact epithelial preparation. A beveled piece of hair was used to plow a furrow through the saccular epithelium $(A)$, revealing basolateral aspects of hair cells $(B)$. Scale bars: $A, 50 \mu \mathrm{m} ; B, 5 \mu \mathrm{m}$.

Hudspeth, 1983; Hudspeth and Lewis, 1988a,b) but strikingly different from what we found in the semi-intact preparation.

Some of the results presented here have appeared in abstract form (Armstrong and Roberts, 1996, 1997).

\section{MATERIALS AND METHODS}

All recordings were made from grassfrog saccular hair cells, and all procedures were performed at room temperature $\left(20-25^{\circ} \mathrm{C}\right)$.

Hair cell preparations. Enzymatically dissociated hair cells were prepared using the same procedure and enzyme (papain 5125; Calbiochem, La Jolla, CA) as in previous experiments on frog saccular hair cells (Lewis and Hudspeth, 1983; Hudspeth and Lewis, 1988a, Roberts et al., 1990; Roberts, 1993). We will refer to this partially purified preparation of papaya (Carica papaya) latex as "papain," although it is known to also contain several other papaya proteases (Brocklehurst and Salih, 1983). The saccular epithelium was incubated for $\sim 30 \mathrm{~min}$ in low-calcium solution (in mM: $110 \mathrm{Na}^{+}, 2 \mathrm{~K}^{+}, 0.05 \mathrm{Ca}^{2+}, 110 \mathrm{Cl}^{-}, 3 \mathrm{D}$-glucose, 5 HEPES) to which $0.25 \mathrm{mg} / \mathrm{ml}$ papain and $2.5 \mathrm{~mm}$ L-cysteine had been added. Cysteine is thought to activate papain by reducing disulfide bonds. After enzyme treatment the sacculus was transferred to lowcalcium solution containing $0.5 \mathrm{mg} / \mathrm{ml} \mathrm{BSA}$ for at least $1 \mathrm{hr}$ to stop the enzyme reaction. The epithelium was then transferred to a recording chamber containing low-calcium solution, in which the hair cells were dissociated by gently rubbing the saccular epithelium with a fine piece of dog hair (Canis familiaris var. Labrador).

Access to hair cells in the semi-intact epithelial preparation was achieved by removing the overlying otolithic membrane and then plowing a furrow (Fig. 1) through the saccular epithelium with a beveled piece of dog hair. The epithelium was then transferred to a recording chamber, mounted, and the debris surrounding live hair cells was removed with a suction pipette. Consistently better preparations were obtained when the epithelium was incubated in low-calcium solution for at least $1.5 \mathrm{hr}$ before the furrow was plowed. Although this preparation gave us access to hair cells throughout the saccular epithelium, no attempt was made to correlate position with variations in membrane properties or to identify the hair cells morphologically.

Recording procedures. Both preparations were visualized on an upright microscope (Zeiss, Thornwood, NY) equipped with a $40 \times$ water immersion objective and differential interference contrast optics. Whole-cell (Hamill et al., 1981) and perforated patch (Horn and Marty, 1988) recordings were made using a Dagan model 3900 patch-clamp amplifier (Dagan Corp., Minneapolis, MN) with active series resistance compensation. Recording pipettes were pulled from either soda-lime (R6; Garner Glass Co., Claremont, CA) or borosilicate glass (Sutter Instrument Co., Novato, CA), coated with Sylgard (type 182; Dow Chemical Co., Midland, MI), and heat-polished to a tip diameter of $\sim 1 \mu \mathrm{m}$. Pipette resistances, measured in standard solutions, were generally 2-6 $\mathrm{M} \Omega$. Correction for the liquid junction potential $\left(V_{\mathrm{jp}}\right)$ at the pipette tip was made using the values for $\mathrm{K}^{+}$-aspartate and $\mathrm{Cs}^{+}$-aspartate internal solutions from previous work $\left(V_{\mathrm{jp}}=-13 \mathrm{mV}\right.$ for both; Roberts et al.,
1990, note error in their Table 1). We measured $V_{\text {ip }}$ for the $N$-methylD-glucamine (NMG) internal solution to be $-5 \mathrm{mV}$. After formation of a tight $(>1 \mathrm{G} \Omega)$ seal on the cell's membrane, electrical access to the interior of the cell was achieved either by rupturing the membrane inside the pipette, allowing the soluble components of the cytoplasm to be replaced by the pipette solution (whole-cell recording), or through the channels formed by the perforating agent nystatin (perforated patch recording; $4 \mu \mathrm{l}$ of a stock solution containing $50 \mathrm{mg}$ nystatin $/ \mathrm{ml}$ of dimethylsulfoxide was added per milliliter of pipette solution). No major differences in voltage or current responses recorded using whole-cell or perforated patch methods were noted.

pClamp6 (Axon Instruments, Foster City, CA) was used to generate voltage- and current-clamp commands and to record the resulting data. Data were filtered at either 5 or $10 \mathrm{kHz}$ and digitized at $20 \mathrm{kHz}$. All voltage-clamp recordings were made from a holding potential of -70 $\mathrm{mV}$, averaged five times, and leak-subtracted using a standard $\mathrm{P} / 4$ protocol. Voltage-clamp commands were applied in $10 \mathrm{mV}$ increments.

Solutions and pharmacological agents. All solutions were adjusted to have a $\mathrm{pH}$ of 7.25 and an osmotic strength of $\sim 220 \mathrm{mOsm}$. The recording chamber was continuously perfused with a perilymph-like solution (normal extracellular solution) containing (in $\mathrm{mM}$ ): $112 \mathrm{Na}^{+}, 2 \mathrm{~K}^{+}, 1.8 \mathrm{Ca}^{2+}$, $0.7 \mathrm{Mg}^{2+}, 119 \mathrm{Cl}^{-}, 3 \mathrm{D}$-glucose, 5 HEPES. This solution differs somewhat from that used in previous work and was formulated to more closely mimic the composition of perilymph (Corey and Hudspeth, 1983a; Bernard et al., 1986). Standard pipette solution consisted of (in mM): 122 $\mathrm{K}^{+}, 114$ aspartate ${ }^{-}, 0.08 \mathrm{Ca}^{2+}, 4 \mathrm{Cl}^{-}, 2 \mathrm{Mg}^{2+}, 5 \mathrm{HEPES}, 1$ EGTA, 1 ATP. Pharmacological agents were applied externally through two- or five-barreled capillary glass pipettes, pulled and cut so that each opening was $\sim 30 \mu \mathrm{m}$ in diameter. Localized perfusion through this system was driven by a Picospritzer II (General Valve, Fairfield, NJ). Solutions containing $>1 \mathrm{~mm}$ pharmacological agents were prepared by equimolar substitution for $\mathrm{NaCl}$. The effective blocking concentration of iberiotoxin (Ibtx) increased from nanomolar to micromolar concentrations during several months of storage at $-80^{\circ} \mathrm{C}$. For this reason relatively high concentrations of Ibtx were used to block the calcium-activated $\mathrm{K}^{+}$ $\left(\mathrm{K}_{\mathrm{Ca}}\right)$ current.

For experiments in which the papain solution was perfused onto the semi-intact preparation, papain $(0.25 \mathrm{mg} / \mathrm{ml})$ and L-cysteine $(2.5 \mathrm{~mm})$ were added to normal extracellular solution (the same concentrations used in the dissociation procedure). In control experiments, papain was heat-inactivated by boiling for $\sim 5 \mathrm{~min}$, either before or after adding the remaining components of the solution. In either case the osmolarity was adjusted to $\sim 220 \mathrm{mOsm}$ after boiling.

Data analysis. Most data analysis was performed using pClamp6. Additional analysis and plotting were performed using Excel 4.0 (Microsoft Corp., Redmond, WA), IgorPro (WaveMetrics, Lake Oswego, OR), and Mathcad (MathSoft, Cambridge, MA). Despite using lowresistance recording pipettes and active series resistance compensation, the residual uncompensated series resistance $\left(R_{\text {series }} ; \sim 4 \mathrm{M} \Omega\right.$ for wholecell recordings and $\sim 15 \mathrm{M} \Omega$ for perforated patch recordings) caused significant errors in the command potential while large currents were 
flowing. For this reason the voltage amplitudes reported in this paper were corrected for errors due to $R_{\text {series }}$. $R_{\text {series }}$ was calculated by dividing the time constant $(\tau)$, fitted to the falling phase of the capacitive transient evoked by a small voltage step, by the membrane capacitance determined from the area under the capacitive transient. The $R_{\text {series }}$ correction made it more difficult to calculate average currents at a given potential, because the corrected membrane potentials varied between cells. Therefore, the data (see Fig. $10 D, E$ ), as well as the average outward current at $-25 \mathrm{mV}$, were calculated by linear interpolation between adjacent voltage points before averaging.

Another consequence of residual $R_{\text {series }}$ was that the recorded membrane currents were low-pass-filtered. The only noticeable effect of this filtering was an apparent slowing of the $\mathrm{Ca}^{2+}$ current activation. To correct for this when measuring $\mathrm{Ca}^{2+}$ current activation kinetics, we deconvolved the digitized current traces shown in Figure 10 using the equation:

$$
I^{\prime}{ }_{\mathrm{m}}(n)=\frac{I_{\mathrm{m}}(n)-I_{\mathrm{m}}(n-1) \cdot e^{-\Delta t / \tau}}{\left(1-e^{-\Delta t / \tau}\right)},
$$

where $I_{\mathrm{m}}(n)$ is the $n$th point in the digitized current trace, $I_{\mathrm{m}}^{\prime}(n)$ is the deconvolved current trace, $\Delta t$ is the digital sampling interval $(50 \mu \mathrm{sec})$, and $\tau$ is the time constant for charging the cell, as described above. Deconvolution reconstructs the unfiltered current waveform, but does not correct for the fact that the voltage step is not instantaneous. For this reason cells with $\tau>0.15 \mathrm{msec}$ were omitted from the data set.

Quality of resonance. As in previous studies of electrical resonance in hair cells, we measured the quality of resonance $(Q)$ using equations that describe a circuit containing a capacitor in parallel with a resistor and inductor connected in series (Crawford and Fettiplace, 1981). The step response of such a circuit is an exponentially damped sinusoidal oscillation having a frequency $(f)$ and a damping time constant, $\tau_{\mathrm{d}}$. Such a system acts as a linear bandpass filter in which $f$ is near the center of the pass band. The width of the pass band is described by:

$$
Q=\left[\left(\pi \tau_{\mathrm{d}} f\right)^{2}+0.25\right]^{1 / 2} .
$$

Larger values of $Q$ correspond to more prolonged oscillations and a more sharply tuned cell.

\section{RESULTS}

\section{Voltage oscillations: variations on the theme of resonance}

Enzymatically dissociated grassfrog saccular hair cells that had been exposed to papain for $\sim 30$ min before mechanical dissociation exclusively exhibited stereotypical electrical resonance (Fig. $2 A$ ), as previously described in bullfrog (Lewis and Hudspeth, 1983; Hudspeth and Lewis, 1988b). In contrast, hair cells in the semi-intact epithelial preparation, which had suffered neither exposure to papain nor dissociation, showed a number of variations on this theme (Fig. 2B-D). The majority (30 of 50) exhibited damped oscillatory responses similar to those found in enzymatically dissociated cells, although at much lower frequencies (Fig. $2 B$ ). The remaining cells exhibited other types of voltage oscillations. Twenty percent (10 of 50) exhibited a spike-like behavior similar to that previously reported in a number of other preparations (Fuchs and Evans, 1988; Fuchs et al., 1988; Sugihara and Furukawa, 1989; Eatock et al., 1993), including bullfrog saccular hair cells (Hudspeth and Corey, 1977). Spike-like oscillations were undamped and, in some cases, actually increased in amplitude during the current step. In cells in which both spiking and damped oscillations were found (Fig. 2C), spiking generally occurred at slightly lower frequencies than the oscillations. Another variation exhibited by some (10 of 50) hair cells in the semi-intact preparation was a sawtooth at the onset of the response (Fig. 2D, arrow). As with the spiking behavior, the sawtooth was usually found during larger amplitude current steps. With loweramplitude current injections, this sawtooth often became the first peak of the voltage oscillation (data not shown).

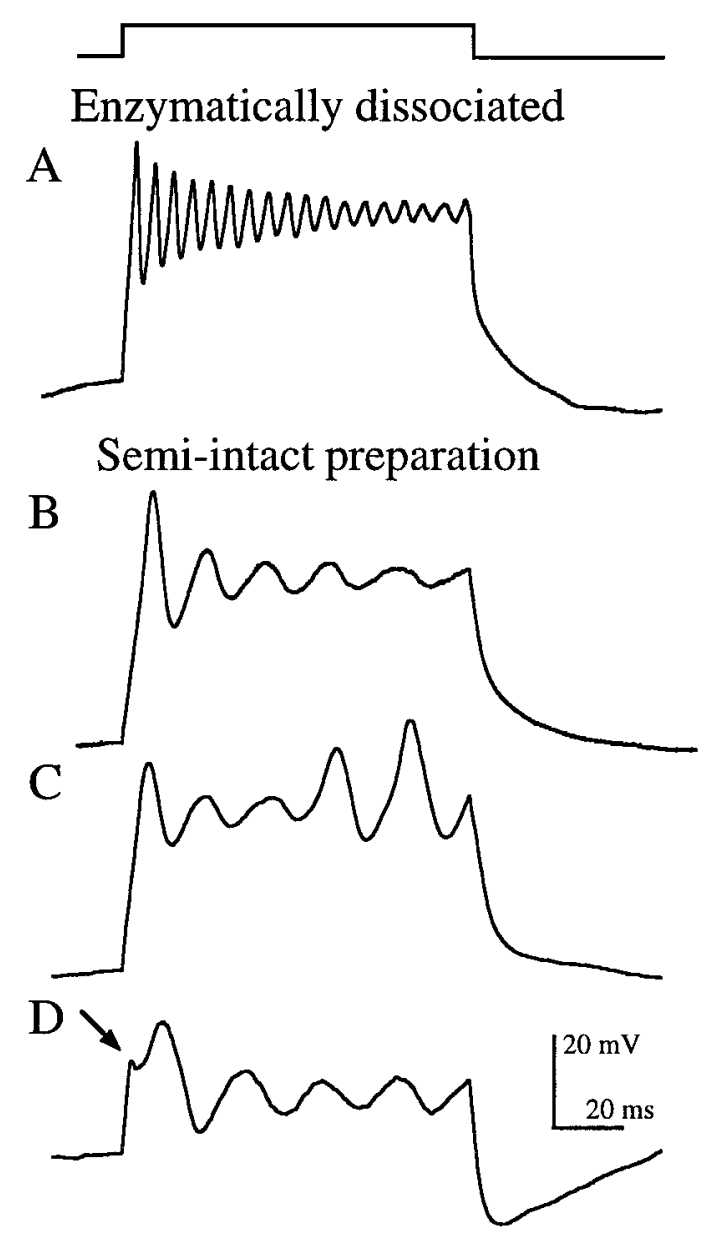

Figure 2. Current-clamp recordings showing stereotypical electrical resonance from an enzymatically dissociated hair cell $(A)$ and the variations seen in the semi-intact epithelial preparation $(B-D)$, evoked by depolarizing current steps (top trace) of amplitude $I_{\text {stim }} \cdot A$, Damped sinusoidal voltage oscillations $\left(I_{\text {stim }}=225 \mathrm{pA} ; f=185 \mathrm{~Hz} ; Q=15.3 ; V_{\text {rest }}=-86\right.$ $\mathrm{mV}) . B$, Damped oscillations $\left(I_{\text {stim }}=100 \mathrm{pA} ; f=59 \mathrm{~Hz} ; Q=2.9 ; V_{\text {rest }}=\right.$ $-91 \mathrm{mV}) . C$, Oscillations that gave way to spike-like behavior $\left(I_{\text {stim }}=125\right.$ $\left.\mathrm{pA} ; f=53 \mathrm{~Hz} ; V_{\text {rest }}=-86 \mathrm{mV}\right) . D$, Sawtooth (arrow) at the onset of the voltage response $\left(I_{\text {stim }}=175 \mathrm{pA} ; f=45 \mathrm{~Hz} ; V_{\text {rest }}=-65 \mathrm{mV}\right)$. Resting potentials $\left(V_{\text {rest }}\right)$ were measured immediately before the step. All recordings were made using perforated patch.

For any given amplitude current injection, enzymatically dissociated hair cells oscillated at approximately three times the frequency of hair cells in the semi-intact preparation (Fig. 3A). For example, the average oscillation frequency $(f)$ evoked by a $100 \mathrm{pA}$ depolarizing current step was $149 \mathrm{~Hz}$ in enzymatically dissociated hair cells (SD, $23 \mathrm{~Hz}$; range, 103-190 Hz; $n=40$ ) and $55 \mathrm{~Hz}$ in hair cells in the semi-intact preparation (SD, $18 \mathrm{~Hz}$; range, $24-105 \mathrm{~Hz} ; n=50$ ). For both populations, $f$ increased with larger amplitude current steps (Fig. $3 A$ ). Average frequencies ranged from 100 to $221 \mathrm{~Hz}$ (total range, 58-271 Hz) in enzymatically dissociated hair cells and from 35 to $75 \mathrm{~Hz}$ (total range, $19-170 \mathrm{~Hz}$ ) in the semi-intact preparation for current injections of $25-400 \mathrm{pA}$.

Another common descriptor of the exponentially damped sinusoidal oscillations seen in most enzymatically dissociated hair cells (Fig. $2 A$ ) is the quality of resonance $(Q)$, a measure of the sharpness of tuning (see Materials and Methods). The more prolonged (less damped) the voltage oscillations, the larger the $Q$ 
A

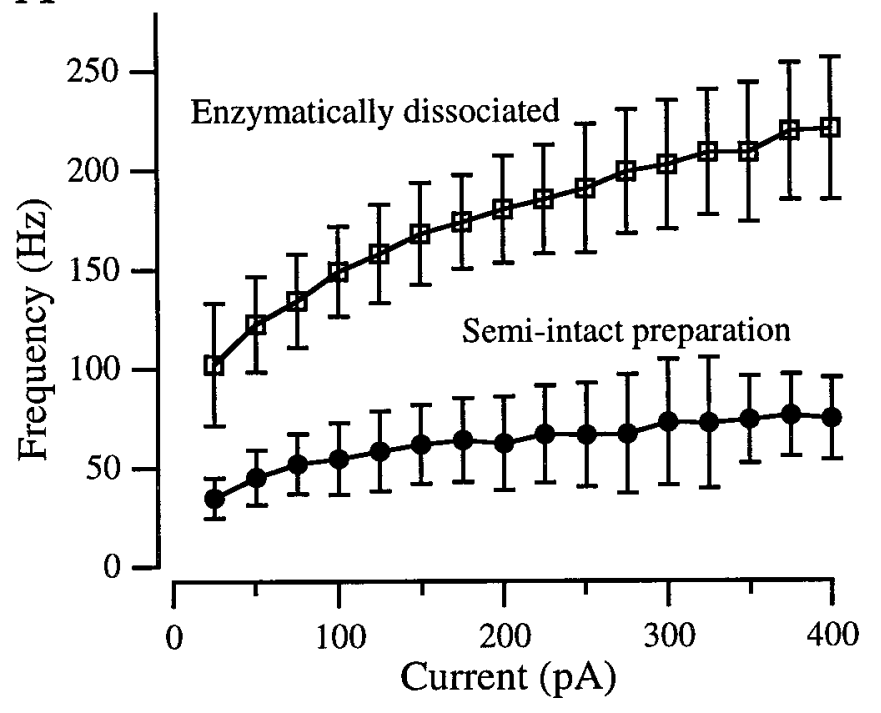

B

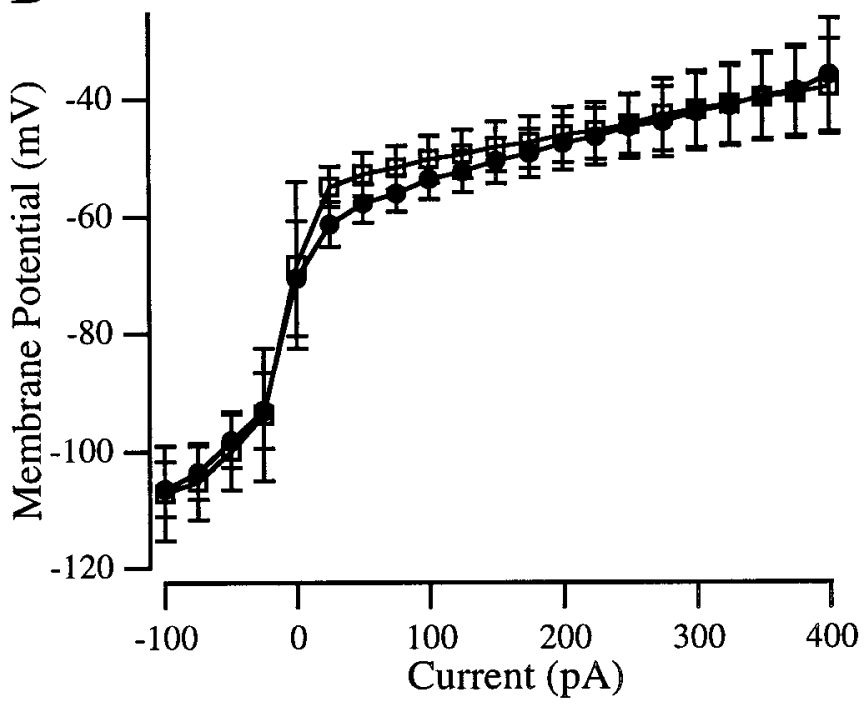

Figure 3. Average current-clamp behaviors of enzymatically dissociated cells $(\square ; n=40)$ and hair cells in the semi-intact preparation $(\bullet ; n=50)$. $A$, Frequency-current relationships. Not all cells oscillated at every current amplitude tested. $B$, Voltage-current relationships. Membrane potential was measured either as the steady-state voltage at the end of the current step or, when the oscillations lasted for the duration of the step, as the average potential around which the cell oscillated. Both panels show mean \pm SD.

value and the more tightly tuned the hair cell is to that frequency. Like $f, Q$ varied with the size of injected current. In most cells, the peak $Q$ was seen during small current steps $(25-100 \mathrm{pA})$ that produced voltage oscillations between -50 and $-60 \mathrm{mV}$. In enzymatically dissociated hair cells, peak $Q$ varied between 2.6 and 166 (median, 13.6; $n=22$ ) and the $f$ at peak $Q$, the frequency to which the cells are expected to be maximally tuned, was $147 \pm$ $34 \mathrm{~Hz}$ (mean $\pm \mathrm{SD}$ ). Cells with high $Q$ values showed little, if any, damping during the $100 \mathrm{msec}$ current step. In the semi-intact preparation, many hair cells exhibited voltage oscillations that were clearly not damped sinusoids (eg., Fig. 2C). The subset of hair cells that did exhibit damped sinusoidal oscillations (eg., Fig. $2 B$ ) had peak $Q$ values that varied from 2.2 to 4.3 (median, 3.3; $n=22$ ) with $f$ at peak $Q$ of $53 \pm 26 \mathrm{~Hz}$ (mean $\pm \mathrm{SD}$ ). Inclusion of the 10 cells that exhibited undamped spike-like behavior $(Q$ assumed to be $\infty)$ raised the median $Q$ to $3.5(n=32)$.

In response to small $(<150 \mathrm{pA})$ depolarizing current steps, enzymatically dissociated hair cells tended to depolarize a few millivolts more than cells in the semi-intact preparation (Fig. $3 B$ ), but otherwise the two populations operated in identical voltage ranges. The average resting potential in both populations was $-68 \mathrm{mV}$, and the range of resting membrane potentials was similar $(-51$ to $-90 \mathrm{mV}$ for enzymatically dissociated hair cells and -57 to $-90 \mathrm{mV}$ in the semi-intact preparation). The very hyperpolarized resting potentials sometimes seen in both preparations may have been caused by loss of the transduction apparatus during dissection, which normally supplies a constant inward current at rest (Corey and Hudspeth, 1983b). Resting potentials were measured before the depolarizing test stimuli; after depolarization the membrane potential of some cells in both populations hyperpolarized to the $\mathrm{K}^{+}$equilibrium potential (approximately $-90 \mathrm{mV}$ ), possibly due to the activation of the inward rectifier $\mathrm{K}^{+}\left(\mathrm{K}_{\mathrm{IR}}\right)$ current that was first noted in bullfrog saccular hair cells (Corey and Hudspeth, 1979), and that has also been found in both grassfrog preparations (Holt and Eatock, 1995; Armstrong and Roberts, 1997). Even without stimulation, some cells from both populations displayed similar bistable membrane potentials.

\section{$\mathrm{K}^{+}$currents in enzymatically dissociated hair cells}

Previous biophysical and modeling studies have attributed the generation of resonance exhibited in enzymatically dissociated bullfrog saccular hair cells to the interplay of a voltage-dependent $\mathrm{Ca}^{2+}$ current with a single outward current, $\mathrm{K}_{\mathrm{Ca}}$ (Lewis and Hudspeth, 1983; Hudspeth and Lewis, 1988a,b). Although a voltage-dependent, delayed-rectifier type $\mathrm{K}^{+}$current $\left(\mathrm{K}_{\mathrm{V}}\right)$ has been found in a number of other species (Fuchs and Evans, 1990; Steinacker and Romero, 1991; Goodman and Art, 1996), and intracellular recordings performed in intact bullfrog sacculus have suggested its presence (Corey and Hudspeth, 1979), this current was not found to contribute appreciably to resonance in enzymatically dissociated bullfrog saccular hair cells. To test for a possible contribution of $\mathrm{K}_{\mathrm{V}}$ to resonance in enzymatically dissociated grassfrog saccular hair cells, we exploited the differential sensitivity of $\mathrm{K}_{\mathrm{V}}$ and $\mathrm{K}_{\mathrm{Ca}}$ currents to pharmacological agents. We used concentrations of 4-AP (1 mM) and TEA (6 mM) that in turtle cochlear hair cells were found to block almost exclusively $\mathrm{K}_{\mathrm{V}}$ and $\mathrm{K}_{\mathrm{Ca}}$, respectively (Goodman and Art, 1996). In all enzymatically dissociated hair cells tested, application of 1 mM 4-AP had no effect on resonance $(n=11$; Fig. $4 A$ ), whereas $6 \mathrm{mM}$ TEA reversibly eliminated resonance in these hair cells $(n=11$; Fig. $4 B)$.

An A-type, inactivating $\mathrm{K}^{+}$current $\left(\mathrm{K}_{\mathrm{A}}\right)$ has also been reported in enzymatically dissociated bullfrog saccular hair cells (Lewis and Hudspeth, 1983; Hudspeth and Lewis 1988a) but is largely inactivated in the voltage range in which these cells resonate (Hudspeth and Lewis, 1988a; Murrow, 1994) and has therefore been considered not to play a role in resonance. Figure $4 A$ supports this conclusion, because $1 \mathrm{~mm} 4-\mathrm{AP}$ is expected to eliminate the majority of $\mathrm{K}_{\mathrm{A}}$ (Thompson, 1977; Murrow, 1994). To more conclusively rule out the possibility that $\mathrm{K}_{\mathrm{A}}$ was involved, we applied $20 \mathrm{~mm} 4-\mathrm{AP}$, a concentration that has been 

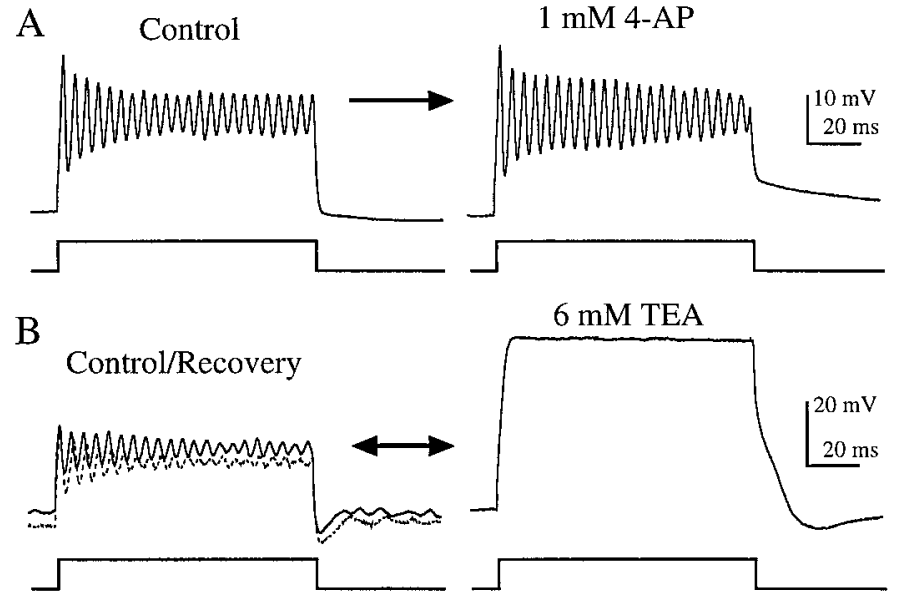

Figure 4. Effects of $1 \mathrm{~mm} 4-\mathrm{AP}$ and $6 \mathrm{~mm}$ TEA on current-clamp recordings from enzymatically dissociated hair cells. $A$, Resonance recorded in normal extracellular solution (control: $I_{\text {stim }}=200 \mathrm{pA} ; f=225$ $\mathrm{Hz} ; V_{\text {rest }}=-72 \mathrm{mV}$ ) was not affected by 4-AP. $B$, TEA reversibly eliminated resonance (control, solid line: $I_{\text {stim }}=200 \mathrm{pA} ; f=222 \mathrm{~Hz} ; V_{\text {rest }}$ $=-52 \mathrm{mV}$ ). Oscillations recovered fully when TEA was removed (recovery, dotted line). Both recordings were made using perforated patch. The records in $A$ are the average of five presentations.

found to be more than sufficient to eliminate $\mathrm{K}_{\mathrm{A}}$ in many types of cells (Thompson, 1977; Lewis and Hudspeth, 1983; Rudy, 1988; Murrow, 1994). This high concentration of 4-AP also had no effect on resonance (data not shown).

Together, these findings support the conclusion that in enzymatically dissociated grassfrog saccular hair cells, as in bullfrog, the only $\mathrm{K}^{+}$current integrally involved in the generation of resonance is $\mathrm{K}_{\mathrm{Ca}}$. The story is, however, quite different and more complex in hair cells that have suffered neither enzymatic treatment nor dissociation from the epithelium.

\section{$\mathrm{K}^{+}$currents in hair cells in the semi-intact preparation}

Comparison of Figures 4 and 5 shows that the effects of $1 \mathrm{~mm}$ 4-AP and $6 \mathrm{mM}$ TEA on hair cells in the semi-intact epithelial preparation were quite different from their effects on enzymatically dissociated hair cells. Application of $1 \mathrm{~mm} 4-\mathrm{AP}$ eliminated voltage oscillations in the majority (11 of 14) of hair cells in the semi-intact preparation (Fig. $5 A$ ). Because, as mentioned above, 1 mM 4-AP is expected to block most of $\mathrm{K}_{\mathrm{A}}$ in addition to $\mathrm{K}_{\mathrm{V}}$, these data do not address whether only one or both of these conductances were involved. Interestingly, the three cells on which 4-AP had no discernible effect also oscillated at higher frequencies (90-125 Hz in response to $100 \mathrm{pA}$ current steps) than the 11 others $(57-76 \mathrm{~Hz})$, making them appear more like enzymatically dissociated cells. Application of $6 \mathrm{~mm}$ TEA to hair cells in the semi-intact preparation never eliminated the oscillations as it did in enzymatically dissociated cells (Fig. 4B). In fact, in the majority ( 8 of 11) of these cells, sinusoidal oscillations were replaced by spike-like behavior (Fig. 5B), similar to the spiking found in some cells in the absence of TEA. This suggests that the cells that spiked in the absence of TEA contained a dominating $\mathrm{K}_{\mathrm{V}}$ current, as in chick cochlea (Fuchs and Evans, 1990) and goldfish sacculus (Sugihara and Furukawa, 1989).

These results indicate that in the preponderance of hair cells in the semi-intact preparation, a voltage-dependent $\mathrm{K}^{+}$current $\left(\mathrm{K}_{\mathrm{V}}\right.$ and/or $\mathrm{K}_{\mathrm{A}}$ ) was integral to the generation of voltage oscillations. Furthermore $\mathrm{K}_{\mathrm{Ca}}$, although present, was not necessary for the
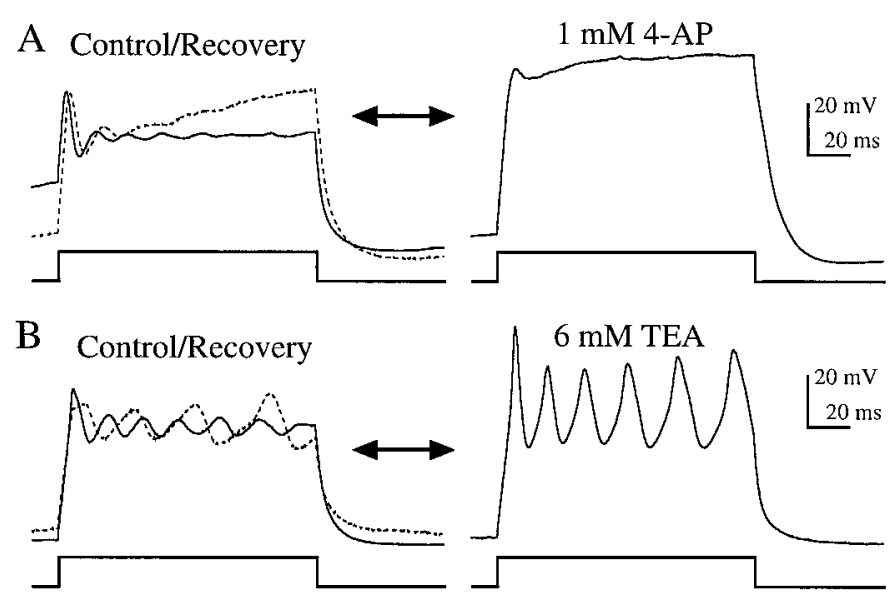

Figure 5. Effects of $1 \mathrm{~mm} 4-\mathrm{AP}$ and $6 \mathrm{~mm}$ TEA on current-clamp recordings from hair cells in the semi-intact epithelial preparation. $A$, Voltage oscillations recorded in normal extracellular solution (control, solid line: $I_{\text {stim }}=225 \mathrm{pA} ; f=82 \mathrm{~Hz} ; V_{\text {rest }}=-70 \mathrm{mV}$ ) were eliminated by 4-AP and partially restored when 4-AP was removed (recovery, dotted line). $B$, TEA transformed the damped sinusoidal oscillations found in this cell (control, solid line: $I_{\text {stim }}=200 \mathrm{pA} ; f=67 \mathrm{~Hz} ; V_{\text {rest }}=-94 \mathrm{mV}$ ) into spike-like oscillations. This effect was partially reversed when TEA was removed (recovery, dotted line). Recordings from both cells were made using perforated patch. The traces in $A$ are the average of five presentations.

generation of voltage oscillations (spikes) in these cells but did appear to play role in modulating the shape of the response.

\section{Voltage-clamp recordings}

We now turn our attention to more directly assessing which ionic currents are present in each hair cell preparation by examining, under voltage-clamp conditions, the time-dependence, voltagedependence, and pharmacological sensitivity of the currents.

\section{Outward currents in enzymatically dissociated hair cells}

Currents recorded from enzymatically dissociated hair cells bathed in normal extracellular solution were remarkably stereotyped. In response to depolarizing voltage steps from a holding potential of $-70 \mathrm{mV}$, a small blip of inward current was rapidly overtaken by a large outward current that reached maximal activation quickly and showed no sign of inactivation at any amplitude voltage tested (Fig. 6A-C, left panels). This outward current was indistinguishable from the $\mathrm{K}_{\mathrm{Ca}}$ current found in enzymatically dissociated hair cells from bullfrog sacculus (Lewis and Hudspeth, 1983; Hudspeth and Lewis, 1988a) and also resembled the $\mathrm{K}_{\mathrm{Ca}}$ currents described in saccular hair cells from fish (Sugihara and Furukawa, 1989; Steinacker and Romero, 1991) and cochlear hair cells from turtle (Art and Fettiplace, 1987), alligator (Fuchs and Evans, 1988), chick (Fuchs and Evans, 1990), and lizard (Eatock et al., 1993). The average current amplitude at the end of a $50 \mathrm{msec}$ step to $-25 \mathrm{mV}$ was $3.9 \pm 0.35$ $\mathrm{nA}$ (mean $\pm \mathrm{SEM} ; n=18$ ). After the return of the membrane potential to $-70 \mathrm{mV}$, we observed decaying outward tail currents that indicate the time needed for the channels to close. In enzymatically dissociated hair cells, the tail current decay after a step to $-25 \mathrm{mV}$ was well approximated by a single exponential with an average time constant of $3.9 \pm 0.24 \mathrm{msec}($ mean $\pm \mathrm{SEM} ; n=17)$.

Our pharmacological dissection of this large, rapidly activating outward current under voltage-clamp conditions is consistent with our current-clamp data that, in turn, agree with previous 
A
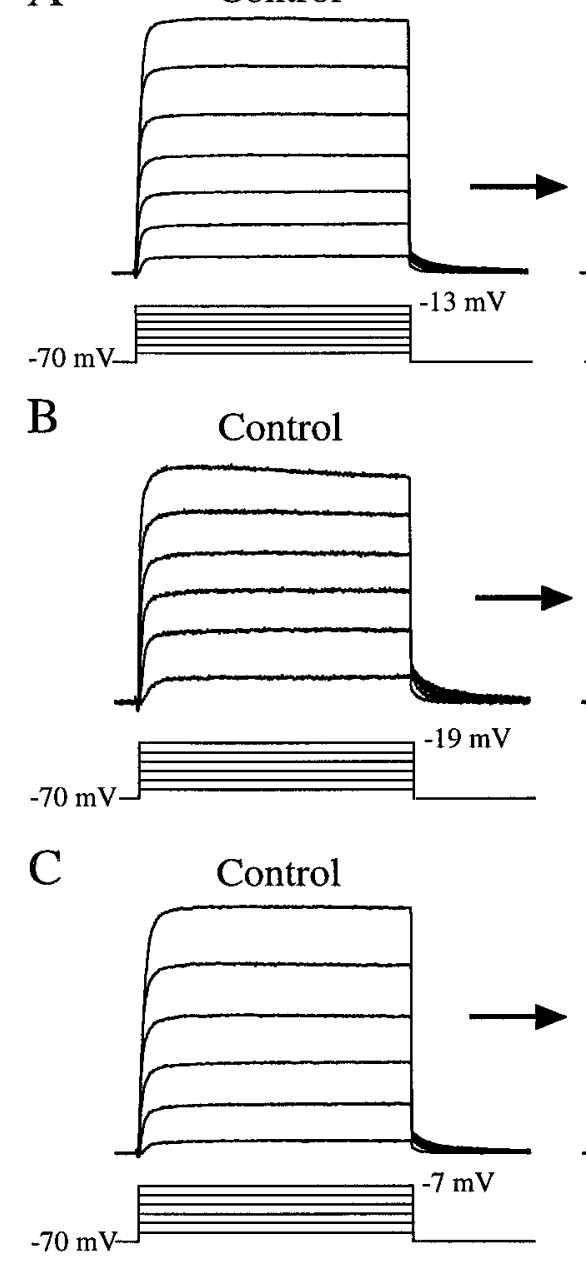
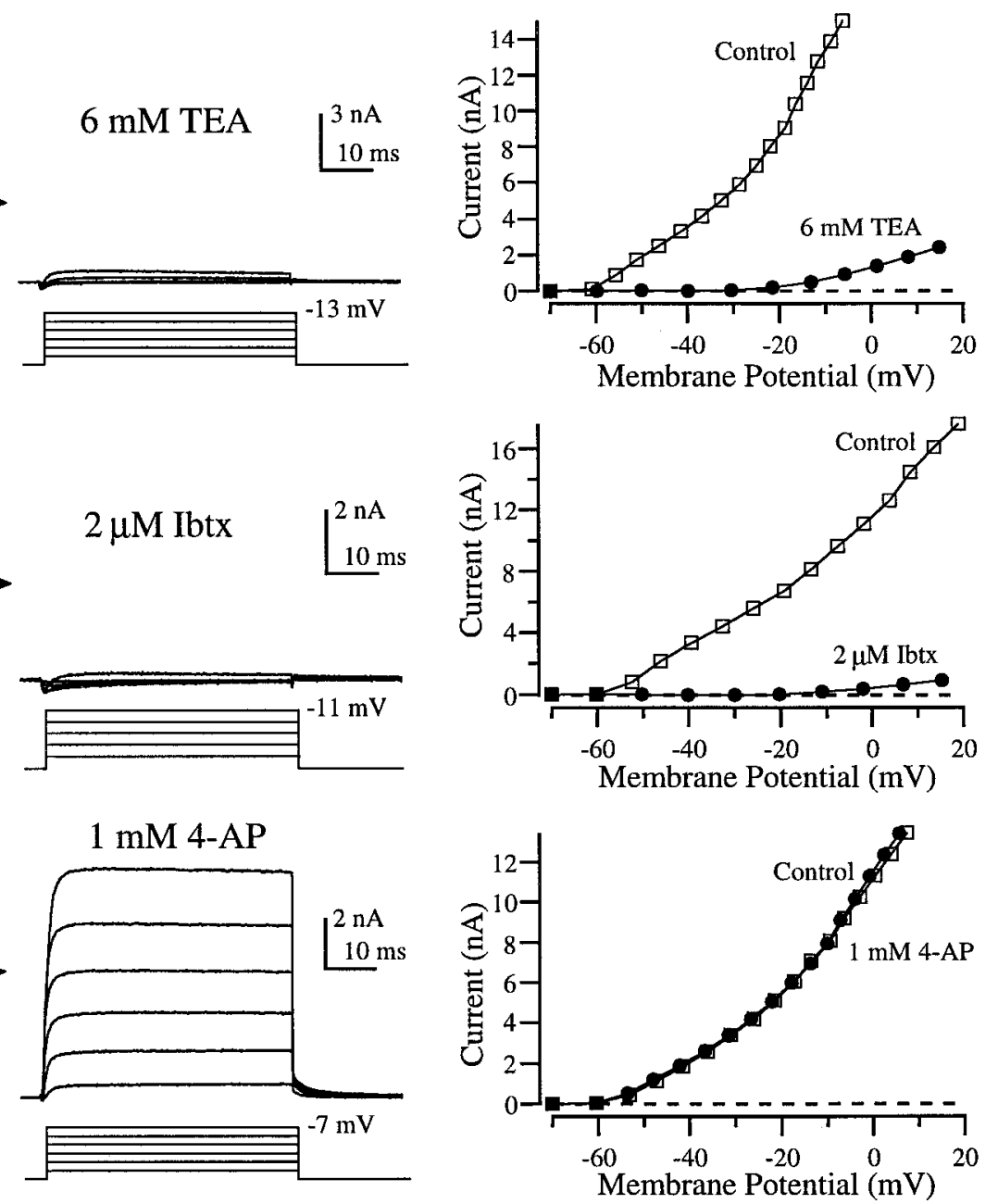

Figure 6. Effects of TEA, Ibtx, and 4-AP on outward currents in enzymatically dissociated hair cells. Essentially all of the outward current recorded in normal extracellular solution (control) was eliminated by $6 \mathrm{~mm}$ TEA $(A)$ or $2 \mu \mathrm{M} \operatorname{Ibtx}(B)$. Application of $1 \mathrm{~mm} 4$-AP $(C)$ had no effect. The panels to the right show the $I-V$ relationship for each cell before $(\square)$ and during $(\bullet)$ drug application. Currents for $I-V$ plots were calculated at the end of each $50 \mathrm{msec}$ step. All recordings were made using a whole-cell configuration and from a holding potential of $-70 \mathrm{mV}$. For each family of traces, the largest amplitude voltage step (corrected for series resistance errors) is indicated next to the step protocol. For clarity, some of the data traces used to construct the $I-V$ plots are not shown.

findings from bullfrog (Lewis and Hudspeth 1983; Hudspeth and Lewis 1988a). Application of 6 mm TEA eliminated all but a small residual outward current (Fig. $6 A ; n=10$ ), as did Ibtx (Fig. $6 B ; n=7)$, a scorpion toxin highly selective for the large conductance $\mathrm{K}_{\mathrm{Ca}}$ channel (Galvez et al., 1990). The ability of Ibtx to eliminate essentially all of the outward current leads us to conclude that only $\mathrm{K}_{\mathrm{Ca}}$ contributed significantly to the outward current in these cells. This conclusion is further substantiated by the observation that $1 \mathrm{~mm} 4-\mathrm{AP}$, a concentration expected to block all of $\mathrm{K}_{\mathrm{V}}$ (Goodman and Art, 1996) and most of $\mathrm{K}_{\mathrm{A}}$ (Murrow, 1994), did not alter the outward current (Fig. 6C; $n=$ 8). Thus, there is no evidence for the contribution of either $K_{V}$ or $\mathrm{K}_{\mathrm{A}}$ to the outward current evoked from a holding potential of $-70 \mathrm{mV}$ in enzymatically dissociated grassfrog saccular hair cells.

\section{Outward currents in hair cells in the semi-intact epithelial preparation}

As in enzymatically dissociated hair cells, depolarizing voltage steps applied to hair cells in the semi-intact preparation evoked a small inward current that was rapidly overtaken by a large out- ward current. However, the shape of the outward current was quite different from that seen in enzymatically dissociated hair cells (compare Figs. 6, 7, left panels). At all voltages the outward current rose quickly, leveled off or decayed slightly, and then continued rising. During large-amplitude voltage steps the current reached a second peak and then decayed, whereas with smaller steps the current was often still rising at the end of the 50 msec step (Fig. 7A-D, left panels). Although nearly all cells in this preparation possessed these major attributes, there was much more variability in the recordings from these cells (Fig. 7, compare left panels) than in enzymatically dissociated hair cells. The average size of the outward current at $-25 \mathrm{mV}$ was $2.0 \pm 0.2 \mathrm{nA}$ (mean $\pm \mathrm{SEM} ; n=21$ ), approximately half that in enzymatically dissociated hair cells, and the time constant for tail current decay was nearly twice as long ( $6.5 \pm 0.2 \mathrm{msec}$, mean \pm SEM; $n=20)$. The complex shape of the outward currents in the semi-intact preparation suggests that more than one conductance was involved. As we shall see, pharmacological dissection supports this hypothesis. 
A

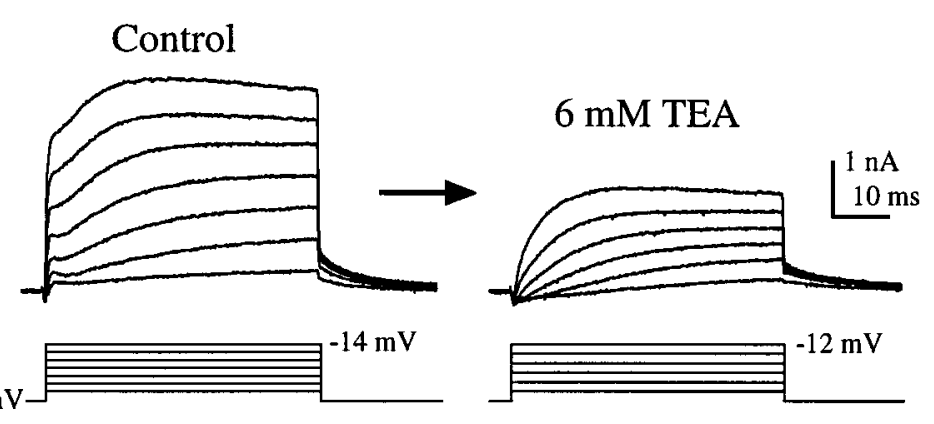

B

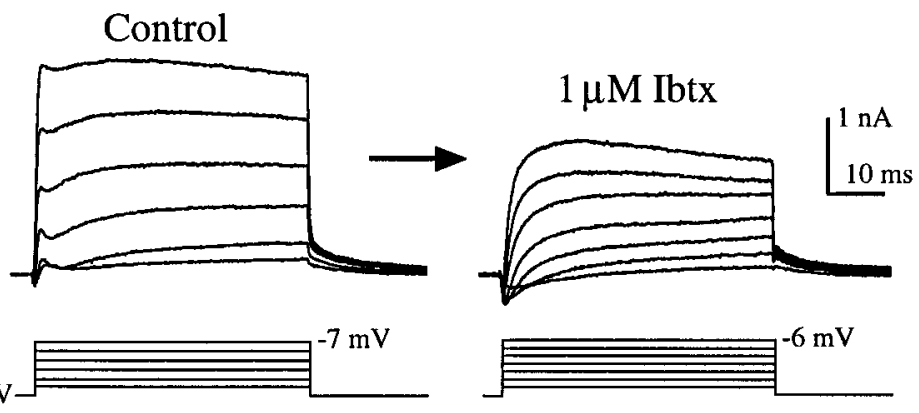

$\mathrm{C}$

\section{Control}

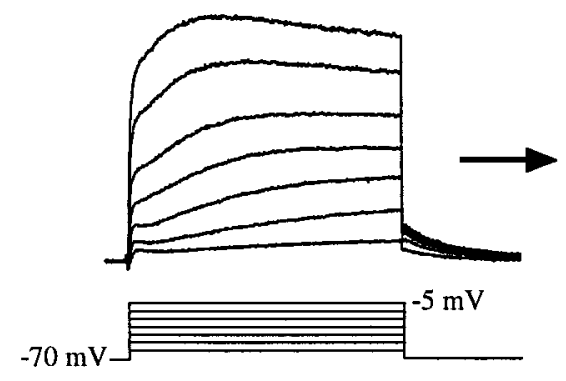

$1 \mathrm{mM} 4-\mathrm{AP}$

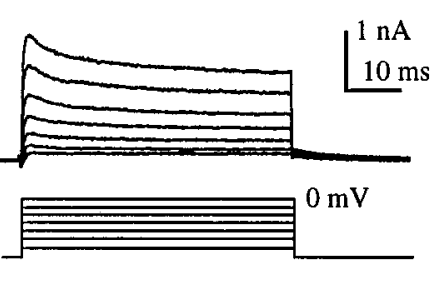

$\mathrm{D}$

\section{Control}

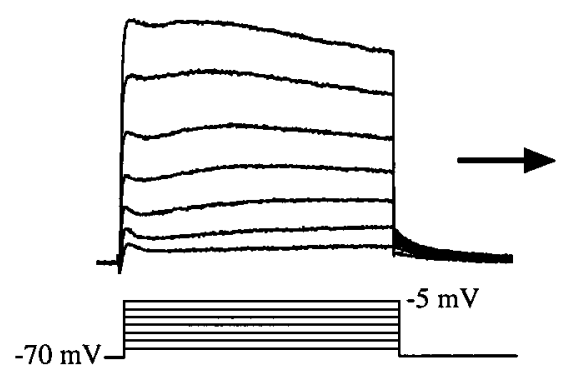

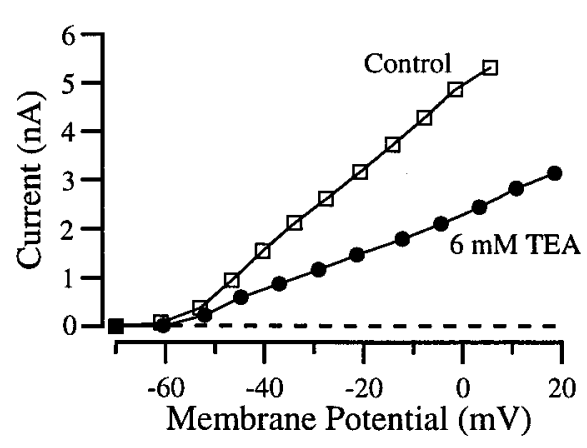
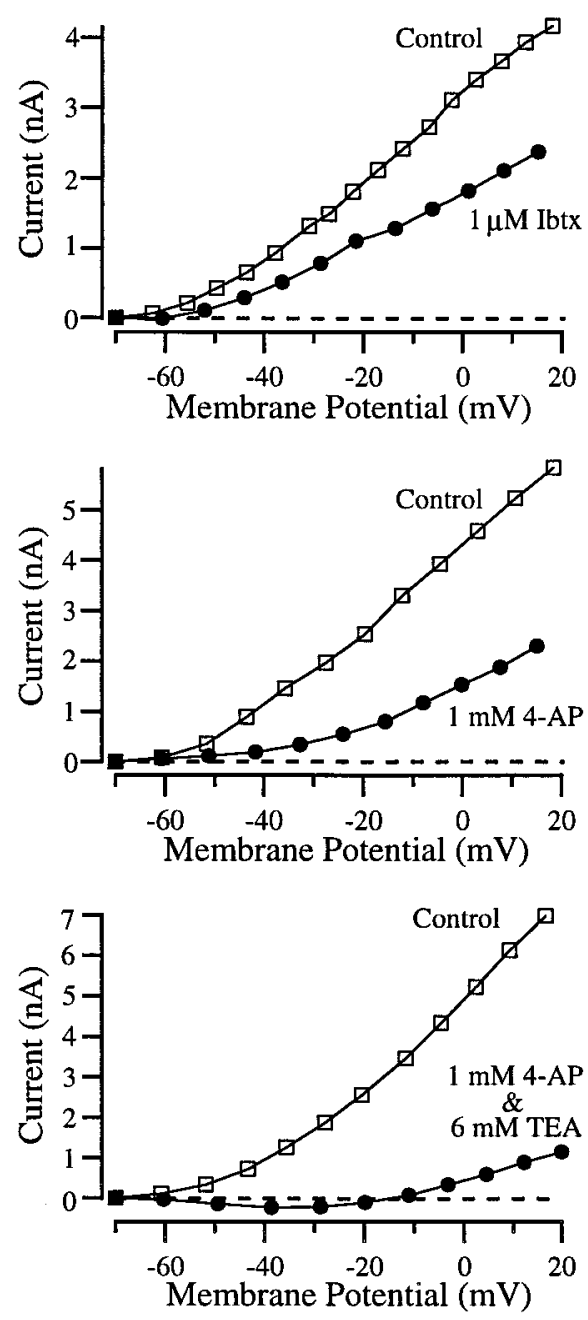

Figure 7. Effects of TEA, Ibtx, and 4-AP on outward currents from hair cells in the semi-intact epithelial preparation. Application of 6 mM TEA $(A)$ or $1 \mu \mathrm{M}$ Ibtx $(B)$ blocked a fast component of the outward current, leaving a more slowly activating component. $1 \mathrm{~mm} 4$-AP $(C)$ blocked a slow component of the outward current, leaving a rapidly activating outward current that partially inactivated. Nearly all outward current was eliminated by applying both $1 \mathrm{~mm} 4-\mathrm{AP}$ and $6 \mathrm{~mm}$ TEA $(D)$. The panels to the right show the $I-V$ relationship for each cell before $(\square)$ and during $(\bullet)$ drug application (see Fig. 6 legend). The recordings in $B$ were made using perforated patch; the others $(A, C, D)$ were made in the whole-cell configuration.

Rather than eliminating nearly all outward current, as in enzymatically treated hair cells, $6 \mathrm{~mm}$ TEA blocked only about half of the outward current in the semi-intact preparation (Fig. $7 A$; $n=8$ ), leaving behind a slowly activating component. Ibtx had a similar effect (Fig. $7 B ; n=5$ ). Application of $1 \mathrm{~mm} 4$-AP also blocked about half of the outward current but left behind a current that activated rapidly and then partially inactivated (Fig. $7 C ; n=8)$. Co-application of 4-AP and TEA eliminated essentially all of the outward current (Fig. $7 D ; n=11$ ).
To visualize the current blocked by each drug, we subtracted the currents recorded during drug application from control currents recorded before drug application (Fig. 8). As suggested by Figure 7, $A$ and $B$, TEA and Ibtx blocked similar components of the outward current (Fig. $8 A, B$ ). In both cases the current sensitive to these agents activated rapidly and then partially inactivated. The differences between Figure $8 A$ and Figure $8 B$ are indicative of the variability between cells, rather than differential effects of the drugs. These subtractions suggest that the TEA- and 


\section{A TEA sensitive}
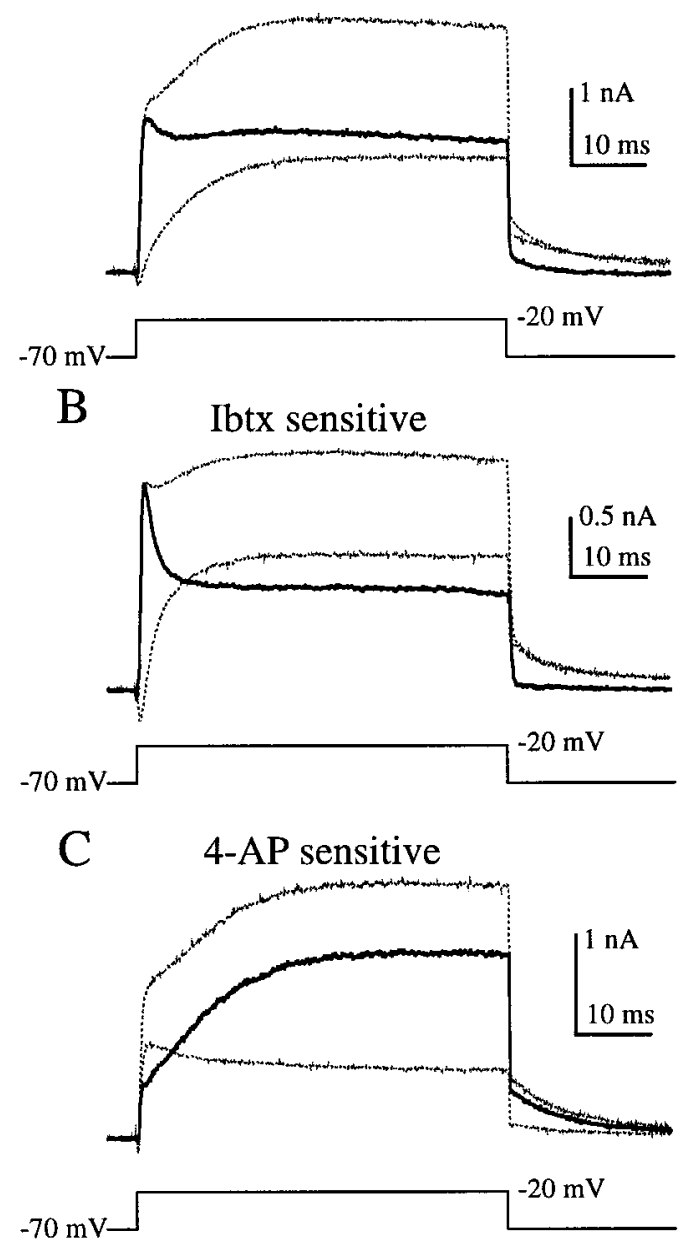

Figure 8. TEA-, 4-AP-, and Ibtx-sensitive currents (dark traces) in hair cells in the semi-intact epithelial preparation obtained by subtracting the currents after drug application (smaller-amplitude light traces) from the currents in control conditions (larger-amplitude light traces). A, Current blocked by $6 \mathrm{~mm}$ TEA activated rapidly and partially inactivated. $B$, One micromolar Ibtx blocked a similar component of the current. $C$, One millimolar 4-AP blocked a slowly activating current. Because of series resistance errors in the step potential it was necessary to estimate the current at $-20 \mathrm{mV}$ by linear interpolation of currents from adjacent voltage steps. These are the same cells as in Figure $8 \mathrm{~A}-\mathrm{C}$.

Ibtx-sensitive current (Fig. $8 A, B$ ) was the same component of the outward current that was insensitive to 4-AP (Fig. 7C). Conversely, the current blocked by $1 \mathrm{~mm} 4$-AP (Fig. $8 C$ ) was similar to the TEA- and Ibtx-insensitive component (Fig. $7 A, B$ ). Together, the TEA- and Ibtx-sensitive component and the and 4-AP-sensitive component constituted nearly all of the outward current (Fig. 7D). Therefore, as previously demonstrated in turtle cochlear hair cells (Goodman and Art, 1996), 6 mM TEA and 1 mM 4-AP seemed to provide a good pharmacological separation of the outward current into two components.

Based on the high specificity of Ibtx for $\mathrm{K}_{\mathrm{Ca}}$ channels, we identified the TEA- and Ibtx-sensitive component as a partially inactivating $\mathrm{K}_{\mathrm{Ca}}$ current. The 4-AP-sensitive component could be $\mathrm{K}_{\mathrm{V}}$, which has been found in other hair cells, or possibly $\mathrm{K}_{\mathrm{A}}$, although this current is expected to be inactivated at the holding potential of $-70 \mathrm{mV}$ (Hudspeth and Lewis, 1988a; Murrow, 1994). Further experiments are under way to more definitively identify these currents.

\section{Transformation of voltage oscillations and outward currents by papain}

So far we have shown that the characteristics of the voltage oscillations and outward currents in enzymatically dissociated hair cells were strikingly different from what we found in the semi-intact epithelium. We now demonstrate that these differences were due to enzyme treatment, rather than dissociation of the hair cells from the saccular epithelium.

Application of the papain solution directly onto the semi-intact preparation, at the same concentration used in the standard hair cell dissociation procedure, transformed the hair cells in situ (Fig. 9). In addition to comparing populations of hair cells in the semi-intact preparation before and after enzyme exposure, we made continuous current-clamp recordings from two cells during papain application. In these cells, enzyme exposure raised the frequency of the voltage oscillations more than three times and metamorphosed the oscillation into a waveform that resembled the stereotypical resonance seen in dissociated hair cells (Fig. $9 A)$. Subsequent application of 6 mm TEA to the cell in Figure $9 A$ reversibly eliminated the voltage oscillations (data not shown). Such an effect of TEA was always observed in enzymatically dissociated hair cells (Fig. $4 B$ ) and never in untreated hair cells in the semi-intact preparation (Fig. $5 B$ ). Likewise, application of the papain solution to hair cells in the semi-intact preparation transformed the outward currents into those typical of enzymatically dissociated cells (Fig. 9B; $n=4$ ). The low quality of the resonance found after papain treatment (Fig. 9A), as well as the reduction in the amplitude of the outward current after treatment (Fig. 9B), effects opposite to those seen in population studies, are likely to be due to rundown that typically occurs during prolonged recording.

The enzyme solution used in these experiments was made by adding papain (a partially purified preparation of papaya latex; see Materials and Methods), plus an activating agent, L-cysteine, to the normal extracellular solution. As a first step in characterizing the active agent in this solution, we tested the effects of omitting or heat-inactivating the papain. No transformation of voltage oscillations or outward currents was seen when normal extracellular solution containing $2.5 \mathrm{~mm}$ L-cysteine without papain was perfused onto hair cells in the semi-intact preparation. Furthermore, hair cells in a semi-intact preparation that had been incubated in heat-inactivated papain (see Materials and Methods) for $30 \mathrm{~min}$ retained low-frequency oscillations and currents typical of untreated hair cells. Thus, we see that some heatsensitive component of papain caused the transformation of the voltage oscillations and outward currents in situ and that dissociation was not required. These results suggest that the proteolytic activity of the enzyme was responsible for the differences in voltage- and current-clamp responses found in these two populations of cells.

\section{$\mathrm{Ca}^{2+}$ current isolation}

To assess whether the enzymatic dissociation procedure affected the $\mathrm{Ca}^{2+}$ current, we blocked the outward currents by substituting the $\mathrm{K}^{+}$in the internal solution with $\mathrm{Cs}^{+}$. Figure $10, A$ and $B$, shows examples of such recordings. A noticeable sag in inward current during depolarizations above $-30 \mathrm{mV}$ was found in the majority ( 9 of 10) of recordings from hair cells in the semi-intact preparation (Fig. 10A) but not in enzymatically dissociated hair cells (Fig. 10B; $n=12$ ). This sag is reminiscent of a current seen in turtle cochlear hair cells that was attributed to $\mathrm{Cs}^{+}$efflux through small-conductance calcium-activated $\mathrm{K}^{+}$(SK) channels 


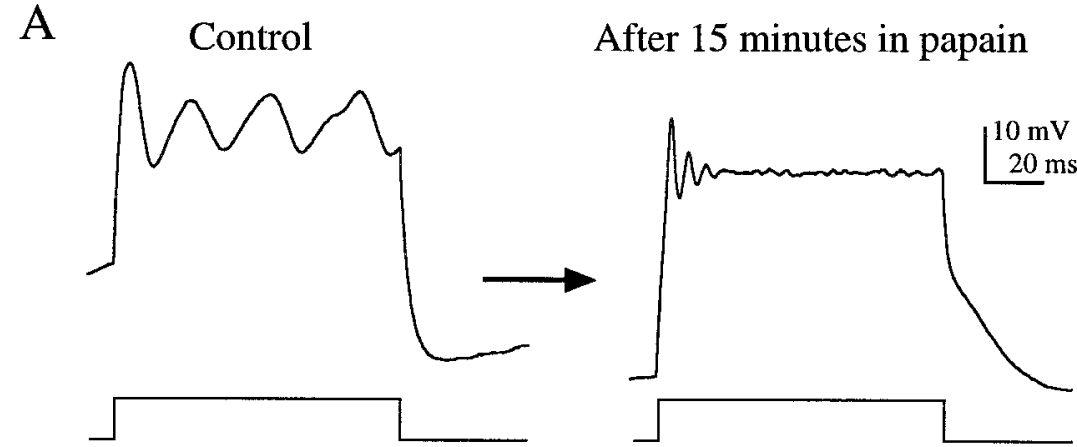

B

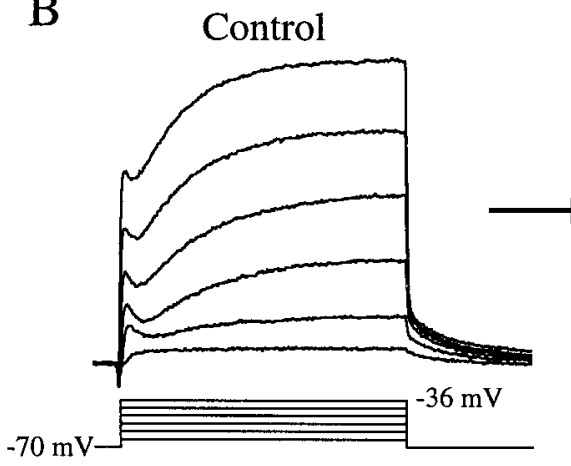

After 21 minutes in papain

(Tucker and Fettiplace, 1996). SK channels in hair cells are thought to be present at the sites of efferent synaptic input and appear to be involved in ACh-mediated hyperpolarization in response to efferent stimulation (Fuchs and Murrow, 1992). Consistent with this interpretation, we found that when $\mathrm{K}^{+}$was replaced by a larger cation, NMG, the sag current was not present in 11 of 13 recordings from hair cells in the semi-intact preparation (Fig. 10C), a result also reported in turtle cochlear hair cells (Tucker and Fettiplace, 1996). Therefore, efflux of $\mathrm{Cs}^{+}$through SK is a likely explanation for this sag in inward current found only in hair cells in the semi-intact preparation and not in enzymatically dissociated cells.

We found no differences in the peak $\mathrm{Ca}^{2+}$ current recorded with $\mathrm{Cs}^{+}$internal solution in the two preparations $(363 \pm 46 \mathrm{pA}$ in the semi-intact preparation and $375 \pm 40 \mathrm{pA}$ in enzymatically dissociated hair cells; mean \pm SEM; $n=10$ and 12, respectively), but we did find differences in the current-voltage relationships and the activation kinetics (Fig. 10D,E). The voltage-dependence of the $\mathrm{Ca}^{2+}$ current in enzymatically dissociated hair cells (Fig. $10 D$, open symbols) was similar to what has previously been reported in enzymatically dissociated bullfrog saccular hair cells (Hudspeth and Lewis, 1988a). The $\mathrm{Ca}^{2+}$ current in hair cells in the semi-intact preparation, however, was shifted $\sim 7 \mathrm{mV}$ in the hyperpolarizing direction (Fig. 10D, filled symbols). The $\mathrm{Ca}^{2+}$ current recorded in this preparation reached half-maximal activation at $-45 \mathrm{mV}$ and peaked at $-22 \mathrm{mV}$, whereas in enzymatically dissociated hair cells it was half-maximal at $-38 \mathrm{mV}$ and maximally activated at $-15 \mathrm{mV}$. This shift cannot be attributed to the presence of SK in the semi-intact preparation, because an $\sim 7$ $\mathrm{mV}$ shift was maintained in recordings made with NMG internally. Additionally, comparison of the currents evoked by voltage steps to approximately $-50 \mathrm{mV}$, a potential at which SK did not appear to be activated, clearly shows that in the semi-intact preparation the $\mathrm{Ca}^{2+}$ current was activated to a much greater extent than in enzymatically dissociated hair cells (Fig. 10, compare $A, B)$.
Figure 9. Papain transforms voltage oscillations and outward currents in the semi-intact epithelium in situ. Traces from continuous perforated patch recordings taken before (control) and after perfusion of papain solution onto the epithelium. A, After $15 \mathrm{~min}$ in papain, the frequency of the voltage oscillations recorded in current-clamp increased from $36 \mathrm{~Hz}$ to $164 \mathrm{~Hz}$. $\left(I_{\text {stim }}=\right.$ $200 \mathrm{pA} ; V_{\text {rest }}=-72 \mathrm{mV}$ in control and $-91 \mathrm{mV}$ after papain treatment). Traces are the average of 10 presentations. $B$, In another cell, the papain solution transformed the outward currents from those typical of hair cells in the semi-intact epithelial preparation (control) into currents typical of enzymatically dissociated hair cells (after $21 \mathrm{~min}$ in papain). The time constant for decay of the tail current after voltage steps to $-36 \mathrm{mV}$ decreased from $6.5 \mathrm{msec}$ before enzyme treatment to 4.4 msec. The largest amplitude voltage step (corrected for series resistance errors) is indicated next to the step protocol.
To compare the activation kinetics of the $\mathrm{Ca}^{2+}$ current in the two preparations we fit the recorded currents with a third order kinetic scheme:

$$
I_{\mathrm{Ca}}(t)=\bar{I}_{\mathrm{Ca}}\left(1-e^{-t / \tau_{\mathrm{m}}}\right)^{3},
$$

where $\bar{I}_{\mathrm{Ca}}$ is the maximal $\mathrm{Ca}^{2+}$ current and $\tau_{\mathrm{m}}$ is the time constant for one of three theoretical gating particles. As reported previously (Hudspeth and Lewis, 1988a), this third-order scheme provided a good fit to the data. The $\tau_{\mathrm{m}}$ versus voltage relationships from the two preparations show that the activation kinetics of the $\mathrm{Ca}^{2+}$ current were voltage-dependent and, with the exception of the point at $-50 \mathrm{mV}$, the kinetics in enzymatically dissociated hair cells were slower than in the semi-intact preparation (Fig. 10E). In the semi-intact preparation $\tau_{\mathrm{m}}$ decreased (the $\mathrm{Ca}^{2+}$ current activated faster) monotonically with increasing depolarization, whereas in enzymatically dissociated hair cells $\tau_{\mathrm{m}}$ reached a peak at $-40 \mathrm{mV}$.

\section{DISCUSSION}

\section{Tuning in isolated hair cells and intact preparations}

Several lines of evidence suggest that tuning can be greatly altered when hair cells are dissociated from the sensory epithelium. Intracellular recordings in the intact turtle cochlea demonstrate that there is good agreement between a hair cells' electrical resonant frequency and characteristic auditory frequency (Crawford and Fettiplace, 1981). However, the range of resonant frequencies exhibited by isolated turtle cochlear hair cells does not match the range of resonant frequencies found in the intact cochlea (Art and Fettiplace, 1987). This type of discrepancy exists in a number of other auditory and vestibular preparations, including frog sacculus (for more detailed discussion, see Eatock et al., 1993). Recordings from afferent axons have shown that the bullfrog sacculus responds maximally to auditory and seismic stimulation at frequencies $<100 \mathrm{~Hz}$ (Lewis, 1988; Yu et al., 1991). In another study of mixed populations of axons from the sacculus 

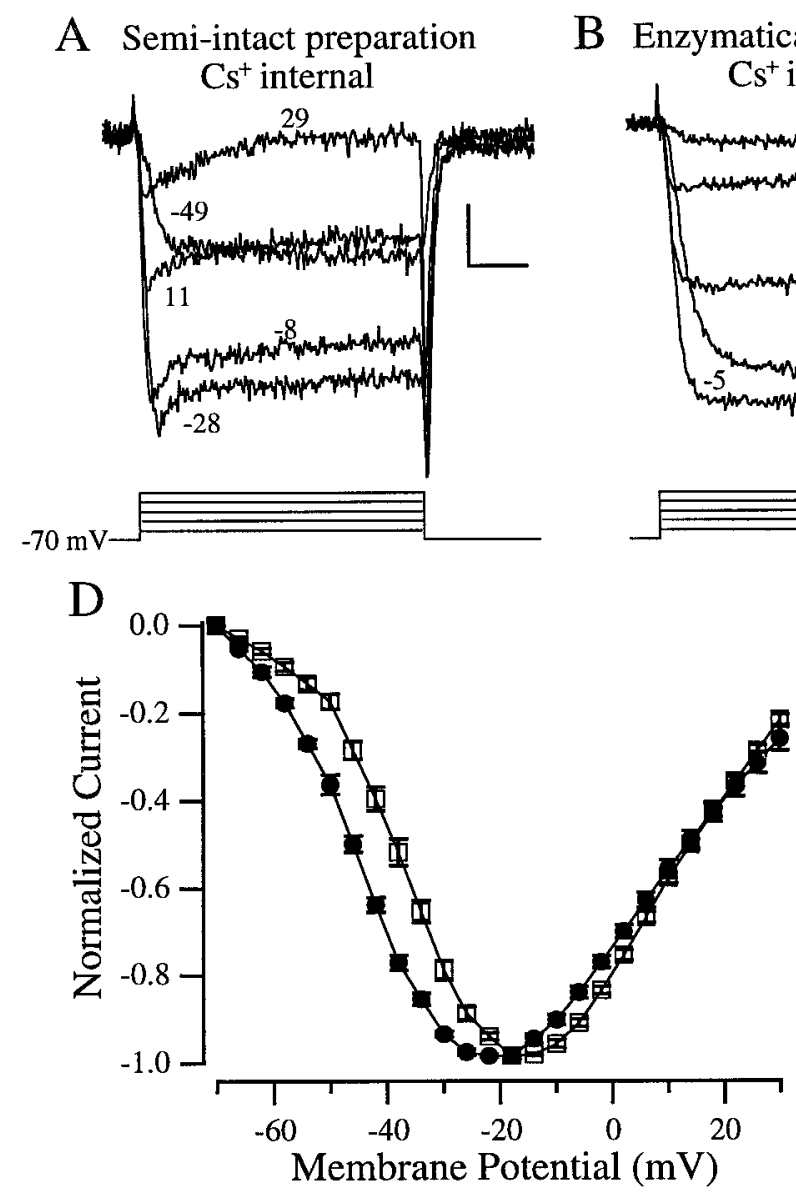

B Enzymatically dissociated

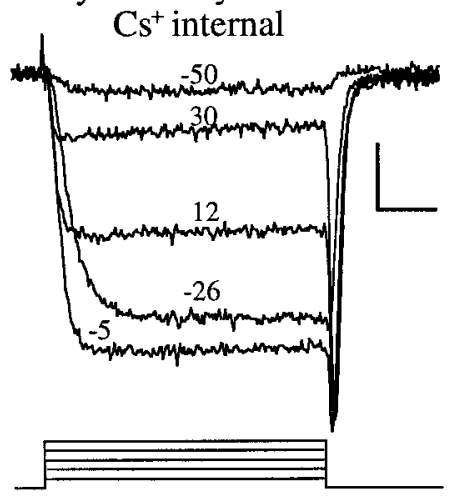

C Semi-intact preparation
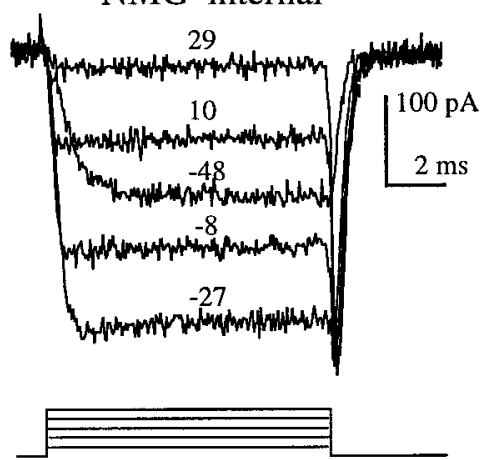

$\mathrm{E}$

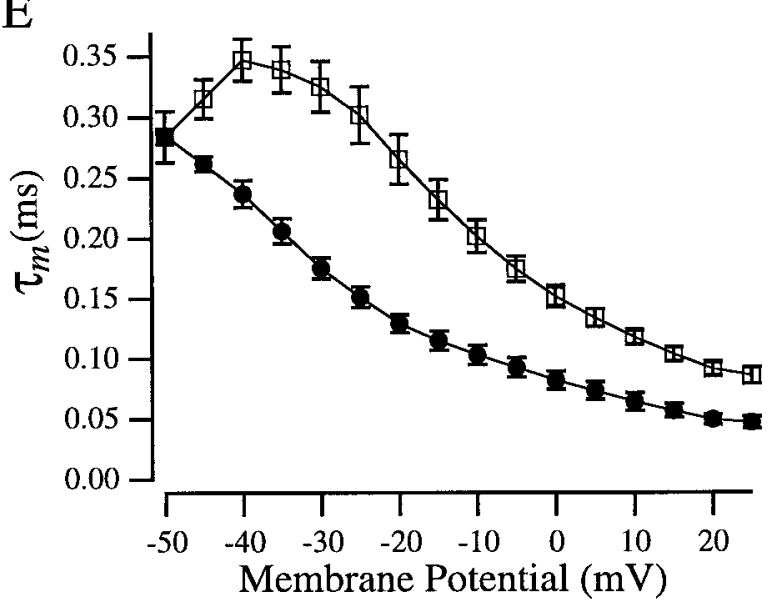

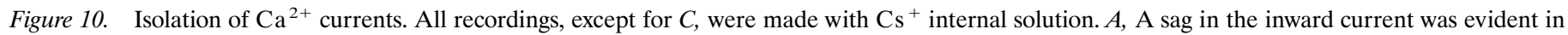

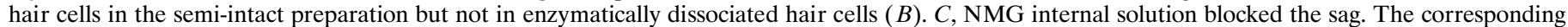

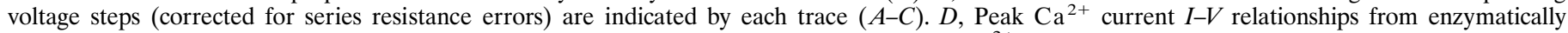

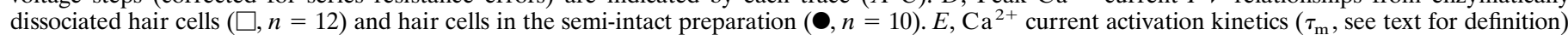

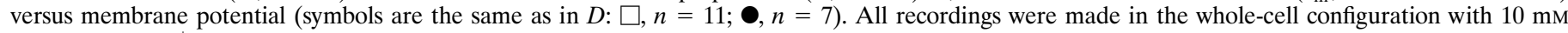
extracellular $\mathrm{Cs}^{+}$to eliminate the activation of a $\mathrm{K}_{\mathrm{IR}}$ current during the leak pulses. Values in $D$ and $E$ are mean \pm SEM.

and amphibian papilla, most axons were maximally sensitive to frequencies between 40 and $70 \mathrm{~Hz}$ (Koyama et al., 1982). Similarly, intracellular recordings from hair cells in the intact saccular epithelium showed that these cells exhibited electrical resonance at frequencies of 11-85 Hz (Ashmore, 1983). In contrast, enzymatically dissociated hair cells from both grassfrog (this work) and bullfrog sacculus (Lewis and Hudspeth, 1983; Hudspeth and Lewis, 1988b) exhibit electrical resonance at frequencies $>100$ $\mathrm{Hz}$. There is also disagreement in the sharpness of tuning. Average $Q$ values from intact saccular preparations were found to be low $(\sim 2)$, suggesting that saccular hair cells are broadly tuned (Ashmore, 1983; Lewis, 1988). In contrast, $Q$ values up to 12.6 have been reported in enzymatically dissociated bullfrog saccular hair cells (Hudspeth and Lewis, 1988b), and in grassfrog we found $Q$ values up to 166 (median $Q=13.6$ ), suggesting that these sensory cells can be tightly tuned to a narrow range of frequencies.

These differences in $f$ and $Q$, in addition to discrepancies in the shapes of tuning curves and the phases of responses, and the small temperature-dependence of tuning, have led several researchers to conclude that hair cells are not exclusively tuned electrically (Lewis, 1988; Eatock et al., 1993; Egert and Lewis, 1995). Instead, they hypothesize that, as in mammals, some form of mechanical feedback is essential for the tuning of auditory and vestibular organs of nonmammalian vertebrates. This intriguing hypothesis has important implications for hair cell tuning in these animals. Accumulating evidence that hair cells from many nonmammalian vertebrate species are capable of exerting forces in response to stimulation (Benser et al., 1996; for review, see Hudspeth, 1997) fits nicely with the idea that mechanical feedback plays a role in tuning. Alternatively, however, it could be argued that these forces are simply a byproduct of transduction. Therefore, the role of mechanical feedback in the tuning of nonmammalian vertebrates remains an open question.

As this study demonstrates, some of the evidence against electrical tuning of the frog sacculus, namely the discrepancies in $f$ and $Q$ noted above, is artifactual and can be directly attributed to the use of papain during cell dissociation. Hair cells in the semi-intact preparation, cells not exposed to papain, exhibited electrical resonance of frequencies between 35 and $75 \mathrm{~Hz}$ and $Q$ values of $\sim 3$. These values are more consistent with those reported from more intact preparations $(f<100 \mathrm{~Hz} ; Q \sim 2)$. Thus, the electrical tuning found in the majority of hair cells in the frog sacculus is sufficient to account for the frequency discrimination of this organ, and the need for a mechanical feedback mechanism 
may not be essential. Further experiments, however, are needed to account for the other discrepancies.

\section{Resonant frequencies and $\mathrm{K}^{+}$conductances}

The Hudspeth and Lewis (1988b) model of electrical resonance shows that the $\mathrm{Ca}^{2+}$ and $\mathrm{K}_{\mathrm{Ca}}$ currents found in enzymatically dissociated frog saccular hair cells are sufficient to explain the stereotypical electrical resonance exhibited by these hair cells. However, as this work demonstrates, this model does not describe the normal operation of these cells but describes the properties of cells that have been distorted by the enzyme used in the dissociation procedure.

Rather than exhibiting exclusively stereotypical electrical resonance, hair cells in the semi-intact preparation, cells not subject to enzyme exposure, showed a variety of voltage behaviors in addition to damped sinusoidal oscillations. Our finding that at least two $\mathrm{K}^{+}$currents $\left(\mathrm{K}_{\mathrm{V}}\right.$ and a $\left.\mathrm{K}_{\mathrm{Ca}}\right)$ rather than a single $\mathrm{K}^{+}$ current are involved in the generation of voltage responses in these cells could explain this diversity. One might imagine that such variety could easily be achieved by varying the relative contribution of each current.

Studies of hair cells from the auditory and vestibular organs of several species have shown that a cell's resonant frequency is determined primarily, though not exclusively, by the properties of its outwardly rectifying $\mathrm{K}^{+}$currents. For example, the tonotopical organization of the turtle cochlea appears to be the result of a smooth gradient in the kinetics of the hair cells' $\mathrm{K}^{+}$currents (Art and Goodman, 1996). Although it remains to be discovered exactly how this gradient in kinetics is set up, this organ seems to use two strategies: varying the kinetics of a single channel type $\left(\mathrm{K}_{\mathrm{Ca}}\right.$; Art et al., 1995) and varying the contribution of fast $\left(\mathrm{K}_{\mathrm{Ca}}\right)$ and slow $\left(\mathrm{K}_{\mathrm{V}}\right)$ outward currents (Goodman and Art, 1996). Whereas hair cells that resonate at frequencies $>100 \mathrm{~Hz}$ contain only $\mathrm{K}_{\mathrm{Ca}}$ currents, and cells that resonate at frequencies $<60 \mathrm{~Hz}$ contain predominantly $\mathrm{K}_{\mathrm{V}}$ currents, cells that resonate in the $50-100 \mathrm{~Hz}$ range express a mixture of $\mathrm{K}_{\mathrm{V}}$ and $\mathrm{K}_{\mathrm{Ca}}$. Hair cells from frog sacculus seem to follow suit. The majority of the hair cells in the semi-intact preparation exhibited voltage oscillations between 35 and $75 \mathrm{~Hz}$ and were found to contain both $\mathrm{K}_{\mathrm{V}}$ and $\mathrm{K}_{\mathrm{Ca}}$. Hair cells that exhibited spike-like oscillations, which we hypothesize contain dominant $\mathrm{K}_{\mathrm{V}}$ currents, oscillated at slightly lower frequencies (generally $<60 \mathrm{~Hz}$ ). Additionally, the few hair cells in this preparation that showed no evidence of containing $\mathrm{K}_{\mathrm{V}}$, the three 4-AP-insensitive cells, oscillated at higher frequencies, between 90 and $125 \mathrm{~Hz}$.

Given that papain alters frog saccular hair cells so dramatically, it is surprising that after enzymatic dissociation these cells exhibit such beautiful oscillatory behavior. Perhaps even more surprising is that enzymatically dissociated hair cells fit nicely in the $\mathrm{K}^{+}$ current versus frequency scheme found in turtle. These cells, which on average resonated at frequencies of 100-221 Hz, were found to contain only a $\mathrm{K}_{\mathrm{Ca}}$ current. Thus, frog saccular hair cells can be transformed from mid-frequency cells, containing both $\mathrm{K}_{\mathrm{V}}$ and $\mathrm{K}_{\mathrm{Ca}}$, to high-frequency cells, containing only $\mathrm{K}_{\mathrm{Ca}}$ simply by exposing them to papain. How this transformation occurs we cannot explain.

\section{Conductances in frog saccular hair cells}

Here we demonstrate that, like a number of other hair cell preparations (Fuchs and Evans, 1990; Steinacker and Romero, 1991; Goodman and Art, 1996), frog saccular hair cells (semiintact preparation) contain a $\mathrm{K}_{\mathrm{V}}$ current. Additionally, these cells were found to contain a transient $\mathrm{K}_{\mathrm{Ca}}$ current, distinctly different from the $\mathrm{K}_{\mathrm{Ca}}$ current found in enzymatically dissociated hair cells. The finding that the $\mathrm{K}_{\mathrm{Ca}}$ current in frog saccular hair cells is transient is very unusual. Although it has been demonstrated that an inactivating $\mathrm{K}_{\mathrm{Ca}}$ current is present in rat chromaffin cells (Solaro and Lingle, 1992), this serves as the only clear demonstration of an inactivating $\mathrm{K}_{\mathrm{Ca}}$ current. Other $\mathrm{K}_{\mathrm{Ca}}$ channels, including the one recently cloned from chick cochlea, cSlo (Jiang et al., 1997), do not exhibit inactivation. We are currently investigating this unusual feature of the $\mathrm{K}_{\mathrm{Ca}}$ current in frog saccular cells.

As in bullfrog (R. catesbeiana), $\mathrm{K}_{\mathrm{A}}$ (Lewis and Hudspeth, 1983; Hudspeth and Lewis 1988a) did not appear to play a role in resonance in enzymatically dissociated grassfrog (R. pipiens) hair cells. Additional experiments will be needed to determine whether hair cells in the semi-intact epithelium have a $\mathrm{K}_{\mathrm{A}}$ current, and if so, whether it plays any role in resonance. Given that this current is expected to be inactivated in the voltage range in which hair cells resonate (Hudspeth and Lewis, 1988a; Murrow, 1994), such a role for $K_{A}$ seems unlikely. We have previously shown that at least one type of $\mathrm{K}_{\mathrm{IR}}$ is present in hair cells in the semi-intact preparation (Armstrong and Roberts, 1997) but have not determined whether both types of $\mathrm{K}_{\mathrm{IR}}$ that have been reported in enzymatically dissociated grassfrog hair cells (Holt and Eatock, 1995) are present. Evidence for a third $\mathrm{K}^{+}$current, SK, was found in hair cells in the semi-intact epithelial preparation but not in enzymatically dissociated hair cells.

Based on its ionic permeability, sensitivity to dihydropyridines, and lack of inactivation (Fuchs et al., 1990; Roberts et al., 1990; Zidanic and Fuchs, 1995), the $\mathrm{Ca}^{2+}$ current in hair cells is thought to be L-type (however, see Su et al., 1995), although it activates at more hyperpolarized potentials than typical L-type currents (Fox et al., 1987). Our finding that the $\mathrm{Ca}^{2+}$ current in hair cells in the semi-intact preparation activated at more hyperpolarized potentials $(\sim 7 \mathrm{mV})$ than in enzymatically dissociated hair cells means that, in this respect, the L-type characteristics of this current are even less typical. Additionally, the activation kinetics of the $\mathrm{Ca}^{2+}$ current in the semi-intact preparation were faster than previously appreciated.

\section{Enzyme effects}

Perhaps our finding that proteolytic enzymes dramatically alter the ionic conductances of frog saccular hair cells is not so surprising. For years it has been known that, when applied intracellularly, proteolytic enzymes can eliminate inactivation of $\mathrm{Na}^{+}$ channels (Armstrong et al., 1973), and more recently, of Shaker $\mathrm{K}^{+}$channels (Hoshi et al., 1990) and $\mathrm{K}_{\mathrm{Ca}}$ channels (Solaro and Lingle, 1992). Although there is less information available on extracellular effects of enzymes, there are reports that dissociation of rod outer segments with papain can alter their electrical properties (Hestrin and Korenbrot, 1987; Shen et al., 1995) and ultrastructure (Townes-Anderson et al., 1985). So, although the finding that enzyme treatment alters ionic conductances may not be surprising, as this study demonstrates, one must use great caution in assessing the properties of cells that have suffered enzymatic digestion; extracellular application of enzymes can dramatically alter the membrane properties of cells.

\section{REFERENCES}

Armstrong CE, Roberts WM (1996) Papain alters the resonant frequency of frog saccular hair cells. Biophys J Abstr 70:A346.

Armstrong CE, Roberts WM (1997) At least three $\mathrm{K}^{+}$currents are 
involved in resonance in frog saccular hair cells. Biophys $\mathrm{J}$ Abstr 72:A355.

Armstrong CM, Bezanilla F, Rojas E (1973) Destruction of sodium conductance inactivation in squid axons perfused with pronase. J Gen Physiol 62:375-391.

Art JJ, Fettiplace R (1987) Variation of membrane properties in hair cells isolated from the turtle cochlea. J Physiol (Lond) 385:207-242.

Art JJ, Goodman MB (1996) Ionic conductances and hair cell tuning in the turtle cochlea. Ann NY Acad Sci 781:103-122.

Art JJ, Wu YC, Fettiplace R (1995) The calcium-activated potassium channels of turtle hair cells. J Gen Physiol 105:49-72.

Ashmore JF (1983) Frequency tuning in a frog vestibular organ. Nature 304:536-538.

Ashmore JF, Kolston PJ (1994) Hair cell based amplification in the cochlea. Curr Opin Neurobiol 4:503-508.

Benser ME, Marquis RE, Hudspeth AJ (1996) Rapid, active hair bundle movements in hair cells from the bullfrog's sacculus. J Neurosci 16:5629-5643.

Bernard C, Ferrary E, Sterkers O (1986) Production of endolymph in the semicircular canal of the frog Rana esculenta. J Physiol (Lond) 371:17-28.

Brocklehurst K, Salih E (1983) A re-evaluation of the nomenclature of the cysteine proteinases of Carica papaya and a rational basis for their identification. Biochem J Lett 213:559-560.

Corey DP, Hudspeth AJ (1979) Ionic basis of the receptor potential in a vertebrate hair cell. Nature 281:675-677.

Corey DP, Hudspeth AJ (1983a) Analysis of the microphonic potential of the bullfrog's sacculus. J Neurosci 3:942-961.

Corey DP, Hudspeth AJ (1983b) Kinetics of the receptor current in bullfrog saccular hair cells. J Neurosci 3:962-976.

Crawford AC, Fettiplace R (1981) An electrical tuning mechanism in turtle cochlear hair cells. J Physiol (Lond) 312:377-412.

Eatock RA, Saeki M, Hutzler MJ (1993) Electrical resonance of isolated hair cells does not account for acoustic tuning in the free-standing region of the alligator lizard's cochlea. J Neurosci 13:1767-1783.

Egert D, Lewis ER (1995) Temperature-dependence of saccular nerve fiber response in North American bullfrog. Hear Res 84:72-80.

Fettiplace R (1987) Electrical tuning of hair cells in the inner ear. Trends Neurosci 10:421-425.

Fox AP, Nowycky MC, Tsien RW (1987) Kinetic and pharmacological properties distinguishing three types of calcium currents in chick sensory neurones. J Physiol (Lond) 394:149-172.

Fuchs PA, Evans MG (1988) Voltage oscillations and ionic conductances in hair cells isolated from the alligator cochlea. J Comp Physiol [A] 164:151-163.

Fuchs PA, Evans MG (1990) Potassium currents in hair cells isolated from the cochlea of the chick. J Physiol (Lond) 429:529-551.

Fuchs PA, Murrow BW (1992) Cholinergic inhibition of short (outer) hair cells of the chick's cochlea. J Neurosci 12:800-809.

Fuchs PA, Nagai T, Evans MG (1988) Electrical tuning in hair cells isolated from the chick cochlea. J Neurosci 8:2460-2467.

Fuchs PA, Evans MG, Murrow BW (1990) Calcium currents in hair cells isolated from the cochlea of the chick. J Physiol (Lond) 429:553-568.

Galvez A, Gimenez-Gallego G, Reuben JP, Roy-Contancin L, Feigenbaum P, Kaczorowski GJ, Garcia ML (1990) Purification and characterization of a unique, potent, peptidyl probe for the high conductance calcium-activated potassium channel from venom of the scorpion Buthus tamulus. J Biol Chem 265:11083-11090.

Goodman MB, Art JJ (1996) Variations in the ensemble of potassium currents underlying resonance in turtle hair cells. J Physiol (Lond) 497:395-412.

Hamill OP, Marty A, Neher E, Sakmann B, Sigworth FJ (1981) Improved patch-clamp techniques for high-resolution current recording from cells and cell-free membrane patches. Pflügers Arch 391:85-100.

Hestrin S, Korenbrot JI (1987) Voltage-activated potassium channels in the plasma membrane of rod outer segments: a possible effect of enzymatic cell dissociation. J Neurosci 7:3072-3080.
Holt JR, Eatock RA (1995) Inwardly rectifying currents of saccular hair cells from the leopard frog. J Neurophysiol 73:1484-1502.

Horn R, Marty A (1988) Muscarinic activation of ionic currents measured by a new whole-cell recording method. J Gen Physiol 92:145-159.

Hoshi T, Zagotta WN, Aldrich RW (1990) Biophysical and molecular mechanisms of Shaker potassium channel inactivation. Science 250:533-538.

Hudspeth AJ (1997) Mechanical amplification of stimuli by hair cells. Curr Opin Neurobiol 7:480-486.

Hudspeth AJ, Corey DP (1977) Sensitivity, polarity, and conductance change in the response of vertebrate hair cells to controlled mechanical stimuli. Proc Natl Acad Sci USA 74:2407-2411.

Hudspeth AJ, Lewis RS (1988a) Kinetic analysis of voltage- and iondependent conductances in saccular hair cells of the bull-frog, Rana catesbeiana. J Physiol (Lond) 400:237-274.

Hudspeth AJ, Lewis RS (1988b) A model for electrical resonance and frequency tuning in saccular hair cells of the bull-frog, Rana catesbeiana. J Physiol (Lond) 400:275-297.

Jiang GJ, Zidanic M, Michaels RL, Michael TH, Griguer C, Fuchs PA (1997) cSlo encodes calcium-activated potassium channels in the chick's cochlea. Proc R Soc Lond B Biol Sci 264:731-737.

Koyama H, Lewis ER, Leverenz EL, Baird RA (1982) Acute seismic sensitivity in the bullfrog ear. Brain Res 250:168-172.

Lewis ER (1988) Tuning in the bullfrog ear. Biophys J 53:441-447.

Lewis RS, Hudspeth AJ (1983) Voltage- and ion-dependent conductances in solitary vertebrate hair cells. Nature 304:538-541.

Moffat AJM, Capranica RR (1976) Auditory sensitivity of the saccule in the american toad (Bufo americanus). J Comp Physiol [A] 105:1-8.

Murrow BW (1994) Position-dependent expression of potassium currents by chick cochlear hair cells. J Physiol (Lond) 480:247-259.

Roberts WM (1993) Spatial calcium buffering in saccular hair cells. Nature 363:74-76.

Roberts WM, Jacobs RA, Hudspeth AJ (1990) Colocalization of ion channels involved in frequency selectivity and synaptic transmission at presynaptic active zones of hair cells. J Neurosci 10:3664-3684.

Rudy B (1988) Diversity and ubiquity of K channels. Neurosci 25:729-749.

Shen J, Watanabe SI, Kaneko A (1995) Cell dissociation with papain reduces the density of cGMP-activated channels of the retinal rod. Jpn J Physiol (Lond) 45:151-164.

Solaro CR, Lingle CJ (1992) Trypsin-sensitive, rapid inactivation of a calcium-activated potassium channel. Science 257:1694-1698.

Steinacker A, Romero A (1991) Characterization of voltage-gated and calcium-activated potassium currents in toadfish saccular hair cells. Brain Res 556:22-32.

Steinacker A, Romero A (1992) Voltage-gated potassium current and resonance in the toadfish saccular hair cell. Brain Res 574:229-236.

Su ZL, Jiang SC, Gu R, Yang WP (1995) Two types of calcium channels in bullfrog saccular hair cells. Hear Res 87:62-68.

Sugihara I, Furukawa T (1989) Morphological and functional aspects of two different types of hair cells in the goldfish sacculus. J Neurophysiol 62:1330-1343.

Thompson SH (1977) Three pharmacologically distinct potassium channels in molluscan neurons. J Physiol (Lond) 265:465-488.

Townes-Anderson E, MacLeish PR, Raviola E (1985) Rod cells dissociated from mature salamander retina: ultrastructure and uptake of horseradish peroxidase. J Cell Biol 100:175-188.

Tucker TR, Fettiplace R (1996) Monitoring calcium in turtle hair cells with a calcium-activated potassium channel. J Physiol (Lond) 494:613-626.

Yu X, Lewis ER, Feld D (1991) Seismic and auditory tuning curves from bullfrog saccular and amphibian papillar axons. J Comp Physiol [A] 169:241-248

Zidanic M, Fuchs PA (1995) Kinetic analysis of barium currents in chick cochlear hair cells. Biophys J 68:1323-1336. 